\title{
The Death of Tamaki Miura: Performing Madama Butterfly during the Allied Occupation of Japan
}

\author{
KUNIO HARA
}

"The Final Stage: Tamaki-San and the Audience in a Chorus of Tears." With this dramatic headline, the Tokyo-based newspaper Jiji Shimpō ran a brief article on March 23, 1946 describing a recital given by Tamaki Miura (1884-1946) that had taken place two days earlier at the Hibiya Kōkaidō in Tokyo. ${ }^{2}$ Trained entirely in Japan, Miura was one of the early pioneers of Western opera in Japan appearing in the performance of Christoph Willibald Gluck's Orfeo ed Euridice in 1903, the first opera production to feature an all-Japanese cast. ${ }^{3}$ Since her debut in London in 1914, Miura also boasted an impressive career as an internationally recognized prima donna known particularly for her vivid portrayal of the title character in Giacomo Puccini's Madama Butterfly (see Figure 1 and Video 1). ${ }^{4}$ Her recital that day featured Franz Schubert's Die schöne Müllerin in her own Japanese translation, reflective of her growing interest in the German Lied during World War II, and concluded with an encore of Henry Bishop's Home! Sweet Home! (see Video 2). In the war-torn capital of Japan, people flocked to witness Miura's performance, perhaps in search of a sign of normalcy in the beauty of the prima donna's celebrated voice. What the audience saw, however, was a mere shadow of the once world-famous soprano; what they heard was a voice that had lost its former luster. The harsh living conditions of the final stages of World War II

Earlier versions of this article were presented at the spring meeting of the American Musicological Society Southeast Chapter in Charlotte, NC in 2011, the Thirteenth Annual University of South Carolina Comparative Literature Conference in 2011 in Columbia, SC, and the Annual Meeting of the American Musicological Society in San Francisco, CA in 2011. Portions of the article also appeared in my PhD dissertation, "Staging Nostalgia in Puccini's Operas" (Indiana University, 2012). I would like to thank the advisers, colleagues, and friends who read one or more versions of this article at various stages to help me refine and enrich my argument: J. Peter Burkholder, Massimo Ossi, Halina Goldberg, Marianne C. Kielian-Gilbert, J. Daniel Jenkins, and Julie Hubbert. I am grateful to Robert Lancefield for sharing his expertise and research materials with me and to the anonymous reviewers for Music and Politics for directing me to invaluable secondary resources. Finally I would like to acknowledge the Office of the Provost's Internal Grant Programs at the University of South Carolina for providing funding for this publication.

1 "Saigo no butai: Tamaki-San to chōshū namida no gasshō" [The Final Stage: Tamaki-San and the Audience in a Chorus of Tears], Fiji Shimpō, March 23, 1946, 2. Unless otherwise noted, all translations from Japanese to English are mine.

${ }^{2}$ Throughout the article, the names of Japanese individuals will be presented in the Western order.

${ }^{3}$ Keiji Masui, Nihon operashi, 1952 [History of Opera in Japan, -1952] (Tokyo: Suiyōsha, 2003), 37-40.

${ }^{4}$ On the life and career of Miura in English, see Arthur Groos, "Return of the Native: Japan in Madama Butterfly/Madama Butterfly in Japan," Cambridge Opera fournal 1, no. 2 (1989): 167-194; Shuhei Hosokawa, "Nationalizing Chō-Chō-San: The Signification of 'Butterfly Singers' in a Japanese-Brazilian Community," Fapanese Studies 19, no. 3 (1999): 253-68; Mari Yoshihara, "The Flight of the Japanese Butterfly: Orientalism, Nationalism, and Performances of Japanese Womanhood," American Quarterly 56, no. 4 (2004): 975-1001; ibid., Musicians from a Different Shore: Asians and Asian Americans in Classical Music (Philadelphia: Temple University Press, 2007), 23-33; Brian Burke-Gaffney, Starcrossed: A Biography of Madame Butterfly (Norwalk, CT: EastBridge, 2004), 127-36 and 165-66; and Robert C. Lancefield, "Hearing orientality in (white) America, 1900-1930" (PhD diss., Wesleyan University, 2004), 69-183. Lancefield's dissertation also contains an extensive list of citations to sources in published in American periodicals during Miura's lifetime. Biographical information about Miura in English can also be found in John Warrack and Ewan West, eds., The Oxford Dictionary of Opera (Oxford: Oxford University Press, 1992), s.v. "Miura, Tamaki”; J. B. Steane in the New Grove Dictionary of Opera, ed. Stanley Sadie, s.v. "Miura, Tamaki." 
and its immediate aftermath had taken a severe toll on her body. In fact, Miura had been hospitalized earlier in the month due to hear rapidly declining health, and her ability to sing was greatly compromised by the time of the recital. During the performance, Miura talked candidly about the severity of her illness and lamented the fact that the recital might be her final public performance. The sight of Miura's emaciated body and the less-than-ideal quality of her voice combined with the knowledge of her imminent death shocked the audience members and moved them to tears. The headline of the article, therefore, succinctly conveys the drama and pathos of the event.

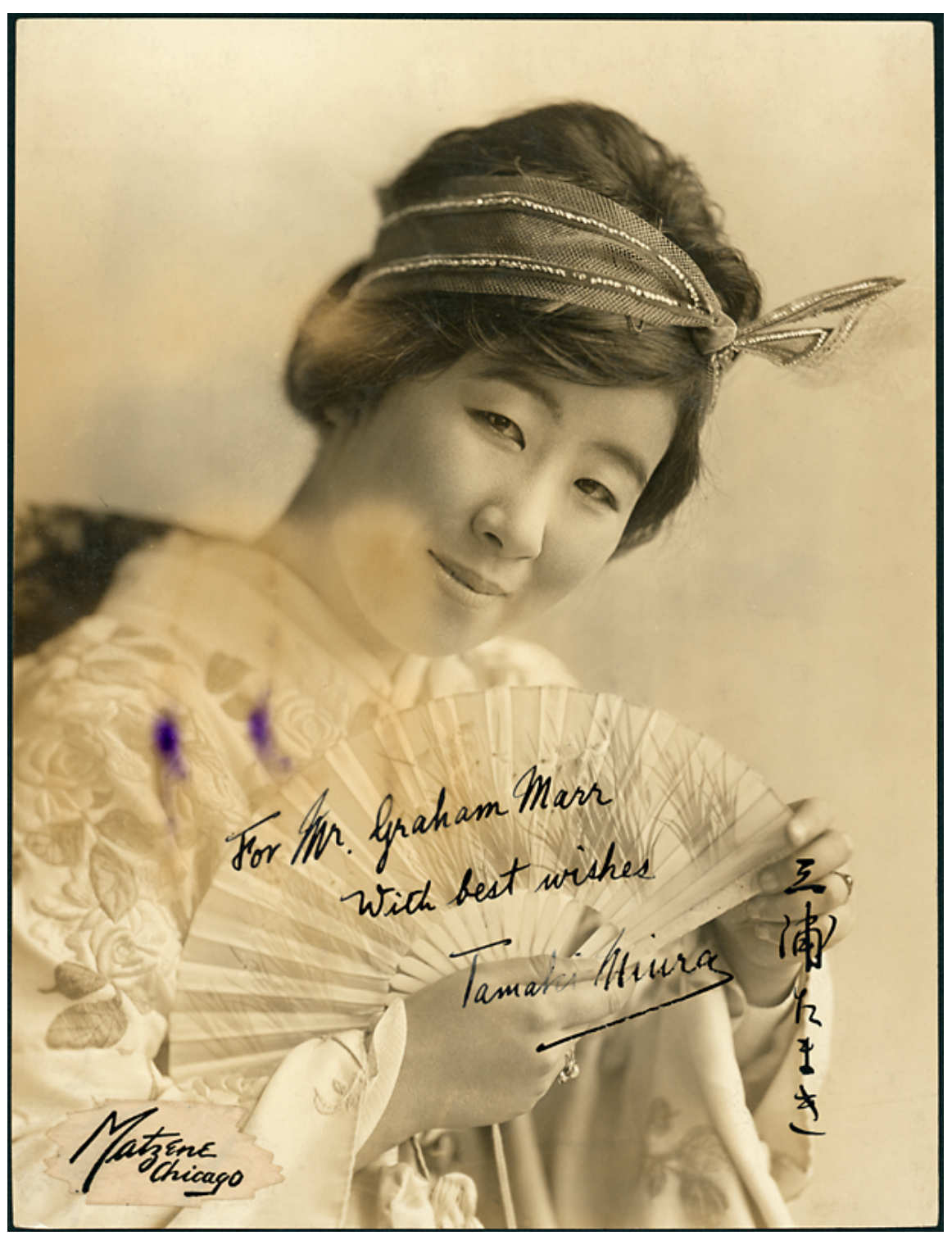

Figure 1. Tamaki Miura around the time of her US debut. Matzene Studio, "Tamaki Miura," sepiatoned gelatin silver print photograph. Chicago ca. 1915-1917. Image courtesy Rob Lancefield.

Video 1. Tamaki Miura’s recording of "Un bel dì vedremo" from Giacomo Puccini’s Madama Butterfly in Italian (Columbia A49260, recorded 1917)

Video 2. Tamaki Miura's prewar recording of Henry Bishop's Home! Sweet Home! in Japanese (Columbia 35317-B, recorded 1932)

View at: http://dx.doi.org/10.3998/mp.9460447.0011.106 
Following the recital, Japan Broadcasting Corporation (NHK) approached Miura and arranged three recording sessions with her. In the following month, Miura recorded, in rapid succession, Schubert's Winterreise on April 5, excerpts from Puccini's Madama Butterfly on April 9, and a selection of Japanese and foreign-language songs on April $16 .^{5}$ A couple of newspapers provided accounts of Miura preparing for and participating in these recording sessions, and NHK broadcast the excerpts from Madama Butterfly nationwide on April 13 in a special program dedicated to the singer. Despite the medical care she received, Miura's health continued to deteriorate in the following weeks. On May 26, just over two months after the recital, Miura died from complications related to abdominal cancer. Her death, in turn, intensified the media's focus on Miura, prompting major Japanese newspapers to print obituaries and commemorative articles as well as reports of her public memorial service and burial rites through the summer (see Figure 2).

\begin{tabular}{|c|c|c|}
\hline Date & Newspaper & Headline \\
\hline October 11, 1945 & Yomiuri Shimbun & "Ōini utau Miura Tamaki-San: Beigunhei ian no ongaku kai de" \\
\hline March 23, 1946 & Jiji Shimpō & "Saigo no butai: Tamaki-San to chōshū namida no gasshō" \\
\hline April 7, 1946 & Mainichi Shimbun & "Omoide no Ochō Fujin: Byōshō ni utau Miura Tamaki-San" \\
\hline April 12, 1946 & Tōkyō Shimbun & "Byōku o oshite Ochō Fujin: Miura Tamaki-San ga AK no maiku e" \\
\hline May 27, 1946 & Asahi Shimbun & "Miura Tamaki-Joshi” \\
\hline May 27, 1946 & Jiji Shimpō & $\begin{array}{l}\text { "Miura Tamaki-San" } \\
\text { "Miura-San no shi: Fujiwara Yoshie" }\end{array}$ \\
\hline May 27, 1946 & Mainichi Shimbun & "Shi no shunkan made utau: Fujiwara Yoshie no hanashi" \\
\hline May 27, 1946 & Yomiuri Shimbun & $\begin{array}{l}\text { "Miura Tamaki-San iku" } \\
\text { "Ōkina sonshitsu: Fujiwara Yoshie no tsuioku" }\end{array}$ \\
\hline May 28, 1946 & Asahi Shimbun & $\begin{array}{l}\text { "Geijutsuka no shi to "kōshū"” } \\
\text { "Tensei Jingo" }\end{array}$ \\
\hline May 28, 1946 & Tōkyō Shimbun & $\begin{array}{l}\text { "Ongaku ni sasageta gekiteki shōgai: Miura Tamaki-San no omoide: } \\
\text { Yamada Kōsaku shi dan" }\end{array}$ \\
\hline May 29, 1946 & Asahi Shimbun & "Chittomo toshi toranu seitai: Tamaki joshi no inkō Tōdai de hozon" \\
\hline June 8, 1946 & Asahi Shimbun & "Ko Tamaki-Joshi no ongakusō” \\
\hline June 8, 1946 & Tōkyō Shimbun & $\begin{array}{l}\text { "Bunka kokka e no mezame sokoku no tame ni geijutsu no tatakai sanjū } \\
\text { nen: ko Miura Tamaki-Joshi ongakusō" }\end{array}$ \\
\hline June 8, 1946 & Yomiuri Shimbun & "Hanayaka ni Miura Tamaki-San ongakusō" \\
\hline June 19, 1946 & Asahi Shimbun & "Tamaki kinen kai no ensō” \\
\hline July 11, 1946 & Asahi Shimbun & "Miura Tamaki-Joshi no maisō shiki" \\
\hline
\end{tabular}

Figure 2. Newspaper Articles about Tamaki Miura, October, 1945-July, 1946

The amount of media coverage devoted to Miura is striking considering the immense social and political upheavals that were taking place in Japan at the time. Miura's final days overlapped with the extraordinary moments in Japan's history during the Allied Occupation that followed Japan's defeat in World War II in the summer of 1945. The Occupation, under the leadership of General Douglas MacArthur, the Supreme Commander of the Allied Powers, inaugurated a range of political, social, and cultural reforms that profoundly impacted the daily lives of the Japanese people at all levels. Reports about Miura's final activities and death in the spring of 1946 came out concurrently with news items about the first postwar general election held on April 10, the various proposals for the revisions to be made to the

\footnotetext{
${ }^{5}$ Hisayuki Tanabe, Kōshō Miura Tamaki [Investigation of Tamaki Miura] (Tokyo: Kindai Bungeisha, 1995), $229-30$.
} 
constitution of Japan, and the International Military Tribunal for the Far East that convened on April 29. In fact, throughout the day that the NHK broadcast Miura's recording of Madama Butterfly, April 13, the radio station reported the early results of the general election that had taken just three days prior. The actual program featuring Miura was aired at 7:30 p.m. immediately following a couple of news programs dedicated to labor news at 7:00 and a report on the war trial at 7:15. ${ }^{6}$ When considering the large number of newsworthy events during this period, it is surprising that the Japanese media outlets paid special attention to an opera singer. This is especially true for the newspapers, many of which were reduced to printing two-page issues at the time. Yet they repeatedly set aside precious space for news about a musician. The presence of a large number of articles in Japanese newspapers over a sustained period of time clearly suggests a considerable appetite for stories about Miura's illness and her eventual death that had exited among their readership.

But what was it about the final days of an aging soprano that Japanese readers living in the unprecedented conditions of the Occupation found meaningful? Did the tragedy of Miura's illness provide a distraction from the harsh realities and countless miseries they faced in their own lives? Or did Miura's unabashedly public demonstrations of her artistic struggles resonate with the public's own challenges for survival? And what did Miura intend and manage to convey about her own legacy through the repeated exposure to the media at the end of her life? A number of scholars in musicology and Japanese studies writing in English such as Arthur Groos, Shuhei Hosokawa, Mari Yoshihara, Brian Burke-Gaffney, and Robert Lancefield have expertly discussed the significance of Miura's career as the first internationally-recognized Japanese prima donna in both Japan and abroad. However, their works focus on Miura's career in the 1910s, 1920s, and 1930s, by-passing the fascinating but artistically less remarkable final chapter of her life. ${ }^{7}$ On the other hand, two Japanese-language studies, Hisayuki Tanabe's biography of Miura, to this day the most comprehensive work of its kind, and Keiji Masui's history of opera in Japan, provide crucial information about the final days of Miura and point to primary sources essential to the current study. ${ }^{8}$ Yet their works do not entail critical interpretation of the information that might answer the question about the immediate postwar preoccupation with Miura's death among the Japanese people as well as Miura's own goals in putting herself in the limelight at the end of her life.

In order to address these long-neglected questions about the Miura's intent in seeking a very public end to her career and the meaning of Miura's death in the cultural context of Occupied Japan, I propose to analyze contemporary newspaper articles listed above in conjunction with a cluster of narratives about Miura's life by herself and others, many of which were produced around the time of her death. Among these narratives, Miura's own recollection of Puccini that she recorded at the NHK studios stands out because of its content and placement within a performance of the opera. During her recording of Madama Butterfly on April 9, Miura inserted her personal reminiscence of her encounter with Puccini in this speech. The speech was broadcast on air as part of the NHK radio program on April 13. Another important text is Miura's so-called "autobiography," co-authored by the music critic Akimitsu Yoshimoto (1899-1960) based on the interviews he conducted with Miura toward the end of her life. Miura died before Yoshimoto could complete his project, but the document was published in a limited edition in 1947, one year after her passing, as Ochō Fujin: Miura Tamaki ikō [Madam Butterfly: Unpublished

\footnotetext{
${ }^{6}$ NHK bangumi kakuteihyō / rajio [NHK Confirmed Scheduled of Programs / Radio], September 1945 through December 1949, NHK Museum of Broadcasting, Tokyo, CD-ROM.

${ }^{7}$ See note 4.

${ }^{8}$ See notes 3 and 5 .
} 
Manuscript of Tamaki Miura]. In addition to the contents of the interviews edited by Yoshimoto, the book includes a commemorative essay by Miura about her mother Towa, "Waga haha" [My Mother]; a diary that Miura kept during the period of hospitalization, "Byōshō shuki" [Sickbed Notes]; and Yoshimoto's own recollection of the final months of Miura's life, "Miura Tamaki no purofiru [Tamaki Miura's Profile]. ${ }^{9}$ Iwao Takahashi's biography, Eien no Chōchō Fujin: Miura Tamaki [The Eternal Madam Butterfly: Tamaki Miura] was published in 1995, well after Miura's death, but it is like Yoshimoto's in that the author intersperses the singer's biographical information culled from other sources with his own personal recollections of Miura based on his close professional interaction with the soprano. ${ }^{10}$ Finally, I include in my analysis Yukio Mishima's short story, "Chōchō" [Butterfly]," which first appeared in the February issue of the literary magazine Hana [Flower] in 1948 and later included in his collection of short stories, Yoru no shitaku [Preparations for the Evening], also published later that year. ${ }^{11}$ The inclusion of a fictional work here may appear unconventional, but it contains a scene from Miura's March 21 recital informed by Mishima's own experience of having attended it. ${ }^{12}$

Although, unlike the newspaper article, this group of documents did not circulate widely, they all contain valuable information about the final days of Miura as well as prevailing opinions and attitudes about the legendary soprano. Of course, relaying information presented in these types of documents uncritically as historical facts, especially in her autobiography, is highly problematic as the theater historian Thomas Postlewait reminds us in his essay on autobiographies of playwrights, actors, theater managers, and other members of the profession. Yet Postlewait also directs our attention to the performative and creative aspects of the performer autobiography, claiming that the genre "delivers the [performer's] public persona in yet another created role, realizing and satisfying the audience's interests and expectations." ${ }^{13}$ In Miura's case, her spoken recollection about Puccini was, in fact, incorporated into her performance and should be treated and interpreted, therefore, as a creative act.

The biographical accounts of Miura produced by those other than the soprano, on the other hand, can also provide valuable information about the society and culture that produced them. Hilary Poriss, in

\footnotetext{
${ }^{9}$ Tamaki Miura, Ochō Fujin: Miura Tamaki ikō [Madam Butterfly: Unpublished Manuscript of Tamaki], ed. Akimitsu Yoshimoto (Tokyo: Yūbunsha, 1947). An excerpt from this autobiography in English appears in Duiti Miyasawa, “Tamaki Miura and Puccini," Opera News, December 10, 1956, 10-11. This biography was reprinted multiple times in subsequent years. The reprint editions include Akimitsu Yoshimoto, ed., "Ochō Fujin: Miura Tamaki jiden” [Madam Butterfly: Tamaki Miura Autobiography] in Sekai no ningenzo [Human Portraits of the World] (Tokyo: Kadokawa shoten, 1961), 2: 361-463; Ochō Fujin: Denki Miura Tamaki [Madam Butterfly: Biography of Tamaki Miura] (Tokyo: Ōzorasha, 1996); and Miura Tamaki, Miura Tamaki: Ochō Fujin, ed. Yoshimoto Akimitsu, Ningen no kiroku 27 (Tokyo: Nihon Tosho Sentā, 1997). Citations to this work refer to the 1997 reprint edition. For further information about the original 1947 edition, see Tanabe, Kōshō Miura Tamaki, 272-74.

${ }^{10}$ Iwao Takahashi, Eien no Chōchō Fujin: Miura Tamaki [The Eternal Madam Butterfly: Tamaki Miura] (Tokyo: Shunjūsha, 1995).

${ }^{11}$ Yukio Mishima, "Chōchō" [Butterfly], in Mishima Yukio zenshū: Ketteiban [Complete Works of Yukio Mishima: Definitive Edition] (Tokyo: Shinchōsha, 2002), 17:11-30. Translated excerpts from the short story in French can also be found in Michel Wasserman, Le tour du monde en deux mille "Butterfly" (L'Isle-sur-la-Sorgue, France: Le Bois d'Orion, 2000), 83-92. Wasserman's monograph also includes an abbreviated biography of Miura.

${ }^{12}$ In addition to the short story, Mishima also wrote a review essay, which remained unpublished during his lifetime. Mishima, "1946 nen 3 gatsu 21 nichi yū no Miura Tamaki dokushōkai” [Solo Recital by Tamaki Miura on the Evening of March 21, 1946], in Mishima Yukio zenshü (Tokyo: Shinchōsha, 2003), 26: 568-71.

${ }^{13}$ Thomas Postlewait, "Theatre Autobiographies: Some Preliminary Concerns for the Historian," Assaph C 16 (2000): 160 and 165. (I express my gratitude to Kimberly White for directing my attention to this source.) In another article, Postlewait recognizes the value of autobiographies as literary texts, observing that the genres of "autobiography and the novel have developed as sibling forms." Ibid., "Autobiography and Theatre History," in Interpreting the Theatrical Past: Essays in Historiography of Performance, ed. Thomas Postlewait and Bruce A. McConachie (Iowa City: University of Iowa Press, 1989), 253.
} 
her examination of the philanthropic activities of a select group of nineteenth-century prima donnas reported in their biographical accounts, seeks to identify "the cultural work that the narratives of their generosity have accomplished." ${ }^{14}$ In a similar manner, I attempt to discern what the narratives of Miura's death accomplished in Japan during the Occupation. Furthermore, Yoshimoto's and Takahashi's recollections of Miura also include digressions into their own memories of living during the final phase of World War II and the early years of the Occupation unrelated to the life and career of the soprano. In her study of the reception of a pair of autobiographies by two French tenors both appearing in 1880, Gilbert Duprez (1806-1896) and Gustave Roger (1815-1879), Kimberly White notes that their publications came during the period of increased self-reflection in France in the immediate aftermath of the Franco-Prussian War of 1870, that promoted the production of such works. ${ }^{15}$ The conclusion of World War II also seems to have created a similar cultural environment that encouraged Japanese writers to produce reflective autobiographical accounts.

Nevertheless, trying to come up with a single interpretation of Miura's death that made sense to the entire population of Japan would be unrealistic. The reactions to the news about Miura's final days would surely have varied between the two positions suggested earlier, between ridicule and empathy. Besides, the question of exactly how Japanese people responded to the news may be ultimately unknowable. Yet it is still possible to discern recurring narrative strands about Miura's life that circulated in the public and to analyze their relationships to other discourses concerning body, war memory, and miscegenation that circulated in Occupied Japan. The Japanese readers' repeated exposure to the narrative tropes in these sources would have surely impacted how they made sense of Miura's onstage and offstage performances and, in turn, tell us about what they valued in them.

Prior to the war, Miura maintained a fraught relationship with the Japanese media, which, on the one hand, celebrated her professional successes but, on the other, frequently criticized her unconventional choices in personal matters that defied the strict norms of the traditional Japanese society. ${ }^{16}$ Yet at this crucial moment in history, Miura, the Japanese media, and the public who consumed the narratives they produced possessed mutually-reinforcing, overlapping interests. Miura's repeated public exposures betrays the urgency that she felt in securing her legacy as one of the preeminent, internationally-recognized artists known for her interpretation of Puccini's Cio-Cio-San. For the most part, the Japanese public took Miura's claim at face value, taking solace, perhaps, in the knowledge that their compatriot once garnered accolades around the world. At the same time, they also saw something else in the courageous acts of the once world-famous prima donna. That is to say that Miura's death provided an opportunity for Japanese people not only to reevaluate Miura's achievements, but also to reflect upon the challenging circumstances of their own lives, as well as the hopes and anxieties about the future of their nation.

In the remainder of the article, I will attempt to untangle the complex web of meaning behind Miura's death by focusing on three recurring patterns in this collection of narratives about Miura. The first is the repeated identification of Miura with the fictional character of Cio-Cio-San. Such association dates back to the early part of her career and has already been documented by several commentators. ${ }^{17}$ What is striking, however, is Miura's extraordinary performative gesture during her final recording of Madama

\footnotetext{
${ }^{14}$ Hilary Poriss, "Prima Donnas and the Performance of Altruism," in The Arts of the Prima Donna in the Long Nineteenth Century, ed. Rachel Cowgill and Hilary Poriss (Oxford: Oxford University Press, 2012), 44.

${ }^{15}$ Kimberly White, “Autobiographical Voices: Singers' Memoirs in fin-de-siècle France” (paper presented at the $4^{\text {th }}$ Biennial North American Conference on Nineteenth-Century Music, Merrimack College, July 16-18, 2015).

${ }^{16}$ Yoshihara, "Flight," 985-90.

${ }^{17}$ Lancefield, "Hearing orientality," 91-137; Yoshihara, "Flight," 981.
} 
Butterfly in which she takes on a creative role that overwhelms Puccini's text. The second is the intense focus on the physical condition of Miura and the quality of her voice during the final phase of her life. The often pathetic and at times gruesome descriptions of Miura's illness and death dwell on the stark juxtaposition between the soprano's decaying body and her powerful desire to sing, prompting their readers to contemplate on the incompatibility of the past and the present, memory and perception. The third is the use of Miura's unflattering demise as a metaphor of Japan in the aftermath of World War II. By making the explicit linkage among Miura, Cio-Cio-San, and the recently defeated Japanese Empire, these narratives attest to the notion that many Japanese conceived of the emerging relationship between their country and the United States in gendered terms. Furthermore, by evoking the tragic figure of the dying Cio-Cio-San that passively accepts her fate to represent the defeated Japan, Miura and her Japanese contemporaries situate themselves squarely in the position of the victims rather than that of the colonial aggressors. The effort to suppress this aspect of the private memory is so successful that very little is studied, to this day, of Miura's activities during Japan's prolonged war with China dating back to 1937 and with the United States and its allies from 1941. We do know, however, that Miura embraced her role as a patriotic singer and participated in war efforts providing musical entertainment for Japanese troops in occupied territories in China. ${ }^{18}$ In 1943, Miura also published an article promoting Japanese songs while expressing her newly found admiration for the German art songs and in the following year vowed never again to perform Madama Butterfly indicative of her sensitivity toward the cultural climate of Japan at the time. ${ }^{19}$ To be certain, even a singer of Miura's caliber would have held little power to shape the cultural policy of wartime Japan. Yet her postwar performance of Madama Butterfly must have functioned as a way for her to forget her participation in the jingoistic activities during the war and to reconnect with happier moments in her past. In the final section of this essay, I consider the last days of Miura-whose career was so heavily indebted to Puccini's Madama Butterfly-against the backdrop of a bourgeoning sex industry that reified the narrative of the opera as a way of tying together the three discernable patterns described above. By subjecting documents to critical scrutiny, particularly by parsing out the ways in which various discourses about Miura were constructed and received, I aim to complement and further the projects of existing scholarship and also call attention to one significant aspect of the dynamic musical culture in Occupied Japan.

\section{Embodying Cio-Cio-San: Miura's Final Recording of Madama Butterfly}

On April 9, 1946, the day when Miura recorded what was to become her final recording of Madama Butterfly, the historical figure of Miura and the fictional character of Cio-Cio-San seemed to coalesce into one. The episode exemplifies perhaps the most telling and crucial element in the narratives about Miura by herself and others: the identification of the singer with the title character of Puccini's opera Madama Butterfly. On the one hand, such doubling was commonplace in written accounts of the singer, whose overseas career was founded largely upon her claim for "authenticity" in portraying the character of CioCio-San based on her nationality. By the end of her career, Miura's association with Madama Butterfly

\footnotetext{
${ }^{18}$ Takahashi, Eien no Chōchō Fujin, 143-60.

19 Tamaki Miura, "Nihon no uta o" [Japanese songs], Ongaku bunka 1 (October 1943): 42; Tanabe, Köshō Miura Tamaki, 400. On the topic of the Japanese musical world during the interwar and war years, see Luciana Galliano, Yōgaku: Fapanese Music in the Twentieth Century, trans. Martin Mayes (Lanham, MD: The Scarecrow Press, 2002), 13-23; and E. Taylor Atkins, Blue Nippon: Authenticating Fazz in Fapan (Durham: Duke University Press, 2001), 127-63.
} 
lasting over 30 years seems to have made her own life interchangeable with that of Cio-Cio-San's in her audience's and her own eyes. ${ }^{20}$ Yet, despite her strong identification with Cio-Cio-San, Miura, during a crucial moment in the recording of Puccini's opera, moved beyond a mere portrayal of an operatic character interjecting her reminiscence of Puccini and a performance of an authentic Japanese song. In a gesture that perhaps recalls the practice of aria insertion from a bygone era, Miura pushes aside the narrative flow of Puccini's opera and asserts her own voice, literally silencing the music of Puccini. ${ }^{21}$ Such a move may seem unexpected or even uncharacteristic especially for a singer who was widely regarded as the embodiment of the essence of Cio-Cio-San's passive "Japanese" femininity. Paradoxically, however, Miura's impetus to rewrite parts of Puccini's opera was predicated upon her intense self-identification with the character of Cio-Cio-San and her desire to promote the artistic value of the work to her fellow Japanese. Conflating her deeply-felt admiration for Puccini and his work with an urgent sense selfpromotion, Miura, an aging prima donna at the brink of her death, aimed to secure and negotiate her legacy in complex ways through her performance of and identification with the figure of Cio-Cio-San.

The documents recounting this event do not necessarily state explicitly the connection between Miura and Cio-Cio-San but present pieces of information that hint at an existence of a close association between the two. According to her own account, Miura attended the recording session dressed in costume as if participating in a staged performance of the opera. She wore a furisode, a type of long-sleeved kimono, pinned her hair (in absence of a wig) to make it look like it was in the traditional shimada style, and decorated it with sprigs of purple and peach-colored hyacinth. ${ }^{22}$ The article in Tokky Shimbun adds a further embellishment not included in Miura's own recollection that the furisode she requested that day had been worn by her on the stage of the Metropolitan Opera House, reminding its readers of her prewar accomplishments. ${ }^{23}$ On the surface, such details may seem to indicate Miura's preoccupation with superficial concerns that had little practical consequence for the recording session at the radio station. Yet anyone familiar with the plot of opera would have realized that Miura's preparation mimicked that of CioCio-San in a critical scene from the opera halfway through Act II. After seeing Pinkerton's ship enter the harbor, Cio-Cio-San, with the assistance of Suzuki, readies herself for what she thinks of as her impending reunion with Pinkerton by asking for the obi (sash) that she had worn on the wedding day, rearranging her hair, and decorating it with a red poppy flower. ${ }^{24}$

\footnotetext{
${ }^{20}$ The linking of Miura's biography with that of a fictional character she championed recalls a similar pattern Mary Ann Smart discusses in her study of the nineteenth-century French diva Rosine Stoltz (1815-1903). Smart argues that accounts produced shortly after the singer's death in the early twentieth century "indulge in an obsessive blurring of art and life: biographies and even newspapers gossip columns overflow with imagined links between Stoltz and her roles." Furthermore, Smart speculates that Stoltz herself, much like Miura, "participated in this process" of linking the real and the fictional by adjusting her behaviors and even her own biography to reflect those of the characters she sang. Mary Ann Smart, "The Lost Voice of Rosine Stoltz," Cambridge Opera Fournal 6, no. 1 (1994): 37.

${ }^{21}$ On the history of the surprising longevity of the practice of aria insertion, see Hilary Poriss, Changing the Score: Arias, Prima Donnas, and the Authority of Performance (Oxford: Oxford University Press, 2009).

${ }^{22}$ Miura, Ochō Fujin, 216.

23 "Byōku o oshite Ochō Fujin; Miura Tamaki-San ga AK no maiku e" [Pushing through despite Her Ailing Body for Madam Butterfly; Mrs. Tamaki Miura in Front of the Microphone at AK], Tōkyō Shimbun, April 12, 1946, 2. Miura sang an excerpt from Madama Butterfly at a war benefit concert at the Metropolitan Opera on May 27, 1918. Miura considered this event one of the highlights of her career, recounting it multiple times in talks and published accounts, including her 1922 article and posthumously published autobiography. Tanabe, Kōshō Miura Tamaki, 210, 254, and 323; Masui, Nihon operashi, 167; “\$75,000 for Red Cross at Theatrical Benefit: Kaiser’s Gold Cup, Auctioned for \$23,000,” New York Times, May 28, 1918, 8; Miura, "Utaitsutsu sekai o meguru" [Traveling the World while Singing], Shinshōsetsu 27, no. 6 (1922): 11; and ibid., Ochō Fujin, 76.

${ }^{24}$ Cio-Cio-San's toilette (toeletta) starts at Act II, Rehearsal Number 82 and ends five measures before Rehearsal Number 89. Giacomo Puccini, Madama Butterfly (Milan: Ricordi, 1999), 368-74. Subsequent references to the score of the opera is to this
} 
Not only the way Miura presented herself but also the circumstances surrounding the recording hinted at the connection she had with the character of Cio-Cio-San. The article in Tokyō Shimbun reports that an American naval officer, Commander "Emu Shī Mein" [M. C. Main?], who had been a devoted fan of Miura from an earlier time, visited the recording studio with two American women in tow. Again, to those familiar with the plot of the opera, Miura's encounter of an American naval officer and American women parallels the dramatic situation in Act II when Pinkerton returns to Cio-Cio-San's house with his new American wife, Kate. Curiously, Miura's own recollection does not mention the presence of the male American officer, but instead only describes one of the American women as a "very, very kind American lady [fujin]" by the name of "Miss Kājan." The American woman was in Japan as part of the Occupation but had heard Miura sing at the Metropolitan. ${ }^{25}$ Miura's account, compared to the newspaper article, follows the plot of the opera more closely: in the opera, Pinkerton departs the scene before he meets CioCio-San, leaving Kate and his friend Sharpless to arrange the transfer of Cio-Cio-San's child to his care. However, the way Miura emphasizes the warmness of "Miss Kājan" through repetition of the word "very" [totemo] suggests a quickly developing bond between the women that is hardly characteristic of the fraught relationship between Cio-Cio-San and Kate Pinkerton. Miura also recalls that, despite her kindness toward her, the American woman became furious at the Japanese doctor for his perceived incompetence at giving injections. ${ }^{26}$ Miura, who lamented the lack of respect accorded to her, especially toward the end of her life, must have appreciated the American woman's concerns for her wellbeing. The reversal of the traditional Japanese gender roles seen in the incidence of a female representative of the Occupation expressing displeasure toward a Japanese male authority figure would also have made a deep impression on her and others as well. In fact, the incidence demonstrates Mire Koikari's argument that "rescuing" Japanese women from the hands of the brutal hands of "barbaric" and "uncivilized" Japanese men was an important theme in the US Occupation of Japan. ${ }^{27}$ The presence of these American spectators at the recording session was obviously something beyond Miura's control but was also reflective of the political situation at the time. Nevertheless, it reminded the Japanese readers and Miura herself of the lasting reach of her fame and added to the theatricality of her final recording. ${ }^{28}$

However, in order to fully appreciate the significance of Miura's performance, a brief description of the contents of the recording session is necessary. The main musical contributions Miura made at the recording session were the arias "Un bel dì, vedremo" and "Con onor muore," 29 which she frequently

\footnotetext{
edition.

${ }^{25}$ Miura, Ochō Fujin, 216.

${ }^{26}$ The doctor is identified as "Shōji” [生司] in Miura's text. This probably is the same doctor referred to as "Shōji” but using a different combination of Chinese characters [荘司] in the Mainichi Shimbun article, “Omoide no Ochō Fujin: Byōshō ni utau Miura Tamaki-San [Madam Butterfly of Her Memories: Mrs. Tamaki Miura Singing at Her Sickbed]," from its April 7, 1946 issue (p. 2).

${ }^{27}$ Mire Koikari, Pedagogy of Democracy: Feminism and the Cold War in the U.S. Occupation of Japan (Philadelphia: Temple University Press, 2008).

${ }_{28}$ Another instance of the overlap between Miura and Cio-Cio-San that at least one Japanese newspaper noted, and the New York Times also relayed, is Miura's conversion to Christianity at her deathbed by the American military chaplain Captain John Griffin Chapman. This act echoes that of Cio-Cio-San's conversion to Christianity that takes place before the narrative of the opera begins. Chapman also gave a prayer at the public funeral held on June 7 in the same venue as her Schubert recital. "Hanayaka ni Miura Tamaki-San ongakusō" [The Brilliant Musical Funeral of Mrs. Tamaki Miura], Yomiuri Shimbun, June 8, 1946, 2; "Mme. Miura Dead; Japanese Singer," New York Times, May 27, 1946. According to the vita included in his dissertation, Chapman served as a member of General MacArthur's staff as "political and social adviser" between 1945 and 1950. John Griffin Chapman, "The Re-Education of the Japanese People” (EdD diss., University of Houston, 1954).

${ }^{29}$ Puccini, who had abandoned the practice of numbering individual items in his opera after his first opera Le Villi (1884),
} 
included in her solo recitals. ${ }^{30}$ Of the two, "Un bel dì" was closely associated with the soprano in Japan, so much so that the reporter for Tōkyō Shimbun identified the aria as Miura's signature number (otokui). ${ }^{31}$ Although not as recognizable as "Un bel dì," "Con onor muore" was another favorite of Miura in her recitals as well. ${ }^{32}$ In fact, between 1917 and 1935, Miura made three recordings each of the two arias in both Italian and Japanese (see Figure 3). ${ }^{33}$ The second aria takes place in the final scene of the opera as Cio-Cio-San prepares herself to commit suicide by reading the inscription on the dagger given to her by her father. When her son Dolore enters the room, she interrupts the ritual for a brief moment and sings an impassioned farewell to the child. In addition to Miura's arias, the accompanying orchestra and the chorus, conducted by the German émigré musician Klaus Pringsheim (1883-1972), also recorded the "Humming Chorus" from the conclusion of Act II, part 1, and other passages that did not involve Miura. ${ }^{34}$ During two of these instrumental and choral passages, Miura broke character and inserted spoken commentaries in her own voice: in the first she summarized the plot of the opera, ${ }^{35}$ and in the other she recounted a meeting she had with Puccini in Italy in the spring of $1920 .^{36}$

When NHK broadcast the contents of this recording session nationally on April 13, they fashioned them into a program that presented the excerpts chronologically, following the structure of Puccini's opera (see Figure 4). The radio program therefore traced the narrative trajectory of Madama Butterfly, but in a severely distorted fashion with an almost exclusive focus on Act II of the opera, erasing the presence of Pinkerton entirely. The desire to showcase Miura's solo singing naturally resulted in the elimination, except for the introduction, of Act I, which contains only a few solo passages for the soprano. ${ }^{37}$ Miura introduced further alteration to Puccini's text with her two orchestrally accompanied speeches that

did not designate these two musical passages as independent arias in his score. Nevertheless, Miura, as well as other singers of her time and after, regularly referred to these and other solo passages as "arias" and included them as such in her vocal recitals.

${ }^{30}$ Just months prior to the recording, Miura had performed both arias for the American troops at several occasions. Tanabe, Kōshō Miura Tamaki, 402-403; Miura, Ochō Fujin, 236-42; Takahashi, Eien no Chōchō Fujin, 195; "Ōini utau Miura TamakiSan: Beigunhei ian no ongaku kai de [Mrs. Tamaki Miura Sings Greatly: At the Concert for Entertaining American Soldiers]," Yomiuri Shimbun, October 11, 1945, 2; and “Mme. Miura Dead: Japanese Singer," New York Times, May 27, 1946, 16.

31 "Byōku o oshite Ochō Fü̈in," Tōkyō Shimbun, April 12, 1946, 2.

${ }^{32}$ The Japanese sources refer to the second aria using different titles: Yoshimoto and Tanabe use the title "Misao ni shinuru wa" [To Die with Honor] (Miura, Ochō Fujin, 243; Tanabe, Kōshō Miura Tamaki, 229), while the entry for Miura's program in NHK's radio logbook refers to it as "Itoshi no gūzō yo" [Beloved Idol]. Yōgaku hōsō kiroku [Record of Western Music Broadcast] (April-May 1946), NHK Museum of Broadcasting, Tokyo. The first title corresponds to the line from the aria, "Con onor muore," when Cio-Cio-San reads the inscription on the dagger bequeathed to her by her father. The second title corresponds to a later line from the aria, "Tu, tu piccolo Iddio!" when Cio-Cio-San sees her child crawling toward her. An article that appeared in the Japanese newspaper Sekai Nippō on May 26, 1948 reports Miura performing "Bōya sayonara" [Farewell My Baby], using yet another variant. This variety reflects the existence of multiple Japanese translations of the opera, but also the difficulty of referring to musical passages that were not designed as independent arias but were nonetheless excerpted in recitals and recordings.

${ }^{33}$ The five-volume CD box set, Miura Tamaki zensh $\bar{u}$, includes an extensive discography by Christopher N. Nozawa in the accompanying booklet (80-87). Tamaki Miura, Miura Tamaki zenshū: Botsugo 50nen kinen [The Complete Works of Tamaki Miura: Commemorating the Fiftieth Anniversary of Her Death], Columbia COCA-12424 $\rightarrow 28$, CD, 1995. See also Tanabe, Kōshō Miura Tamaki, 452-64.

${ }^{34}$ Miura, Ochō Fujin, 216 and 243.

${ }^{35}$ In her diary, Miura describes this as an "explanation." Yoshimoto notes that Miura told the "story" of Madama Butterfly in his recollection: Miura, Ochō Fujin, 216 and 243. NHK's logbook, Yōgaku hōsō kiroku, simply refers to Miura's speech as "talk" (hanashi) and records that the music accompanying this was from Act II, scene 1, without any further information. ${ }^{36}$ Tanabe, Kōsho Miura Tamaki, 219-21, 329; and Masui, Nihon operashi, 167. The news of Miura's visit with Puccini reached Japan only few days after the event. "Kōkashu o eta sakkyokuka Pu-Shi Tamaki-Fujin o yorokobi mukau" [Composer Mr. P. Who Gained an Excellent Singer Gladly Welcomes Madam Tamaki], Tōkyō Asahi Shimbun, April 25, 1920.

${ }^{37}$ Miura made three recordings of passages from the Act I duet with Pinkerton, "Vogliatemi bene," "Bimba dagli occhi pieni malìa," and "Dicon che oltre mare." See Figure 3. 
reflected the singer's idiosyncratic habit of talking directly to the audience members during her recitals. ${ }^{38}$ Finally, Miura's more extensive and personal second speech demonstrates her unusual act of gaining control over the discourse, momentarily exceeding Puccini's orientalist depiction of Cio-Cio-San as a passive heroine who quietly surrenders to her tragic fate.

\begin{tabular}{llll} 
Date & Label/Cat. Number & Item & Language \\
\hline November 9, 1917 & Columbia A49260 & Madama Butterfly, "Un bel dì, vedremo" & Sung in Italian \\
November 9,1917 & Columbia A49265 & Madama Butterfly, "Vogliatemi bene" & Sung in Italian \\
July 1922 & Nipponophone 5178 & Madama Butterfly, "Con onor muore" & Sung in Italian \\
May 31, 1929 & Victor 4149A & Madama Butterfly, "Un bel dì, vedremo" & Sung in Japanese \\
May 31, 1929 & Victor 4149B & Madama Butterfly, "Con onor muore" & Sung in Japanese \\
June 10, 1932 & Columbia 35295A & Madama Butterfly, "Un bel dì, vedremo" & Sung in Japanese \\
November 18, 1935 & Columbia 35480A & Madama Butterfly, "Con onor muore" & Sung in Japanese \\
April 2, 1937 & Columbia 35500B & Madama Butterfly, "Bimba dagli occhi pieni malìa" & Sung in Japanese \\
February 2,1937 & Columbia 35502B & Madama Butterfly, "Dicon che oltre mare" & Sung in Japanese
\end{tabular}

Figure 3. Tamaki Miura's Phonographic Recordings of Madama Butterfly

1. Act I Opening Music

2. Act II Scene 1

3. Act II Scene 1, "Aru hareta hi ni” [Un bel dì]

4. Act II Scene $1 \quad$ (Speech)

5. Act II Scene 2, "Itoshi no gūzō yo “ [Tu, tu piccolo Iddio!]

(Speech)

Figure 4. Items Listed on Yōgaku hōsō kiroku for the Broadcast on April 13, 1946

The recording of this speech is readily available today in a retrospective compact disc compilation of the soprano's historic recordings issued in 1993 by the Japanese label Vintage. ${ }^{39}$ The track on the CD that includes Miura's second speech has the title "Pucchīni no omoide Sanjüsangendō" [Recollection of Puccini-Sanjūsangendō] and begins with the music from Act II, part 2, Rehearsal Number $4 .^{40}$ After a few seconds of the instrumental music, Miura's voice is heard, overlapping with Puccini's music for a brief moment. Eventually the orchestra and the chorus drop out, yielding the stage to Miura alone, who temporarily halts the progress of the narrative of the opera. Although ostensibly about Puccini, the speech emphasizes Miura's accomplishments as an international prima donna and even threatens to relegate the composer to a secondary role, using his work as a vehicle for her success.

\footnotetext{
${ }^{38}$ Yoshimoto states that "Miura-San always gave a talk after performing a solo singing on stage.” Miura, Ochō Fujin, 234. In Uno Chiyo's fictionalized account of the soprano, the character Motoyoshi Miura claims that Miura was advised by the Japanese industrialist and her supporter Eiichi Shibusawa to speak in front of her American audience to overcome her shyness. "Miura Tamaki no henrin" [Fragment of Tamaki Miura] in Wakaremo tanoshi (Tokyo: Shūeisha, 1991), 259-60. In his biography of the soprano, Tanabe suggests that the character of Motoyoshi was based on Miura's manager and adoptive son Motoyoshi Inoue (246). In his dissertation, Lancefield analyzes a report that appeared in the October 14, 1926 issue of Musical Courier that quotes Miura recounting about her experience of talking directly to the audience before performing. "Miura's Tour Solidly Booked," Musical Courier, October 14, 1926, 6, quoted in Lancefield, "Singing Orientality,” 162.

${ }^{39}$ Tamaki Miura, Densetsu no purima Miura Tamaki: debyūban kara saigo no rokuon made [The Legendary Prima Donna Miura Tamaki: From the Debut Disc to the Last Recording], Vintage SYC-1001, CD, 1993.

${ }^{40}$ Yógaku hōso kiroku erroneously indicates that the second talk was recorded over music from Act II, scene 1 (i.e., part 1), but the 1993 recording demonstrates that Miura's second speech is recorded over the opening passages from Act II, part 2.
} 
Miura opens her speech with a few words about Puccini and the playwright, John Luther Long, and quickly turns to her own career, highlighting her achievement of performing Madama Butterfly over two thousand times and then listing the famous tenors with whom she collaborated. In the middle portion of the recollection, Miura relates her 1920 encounter with Puccini, starting with her performance of the opera at the Teatro Costanzi in Rome, which caught the composer's attention. The narrative then turns to Miura's visit to Puccini's villa in Torre del Lago, where Puccini showed her the piano on which he had composed Madama Butterfly. When Puccini asked her to sing "something Japanese" for him, Miura responded with a performance of a famous tune from the eighteenth-century giday $\bar{u}$ play Sanjūsangendo munagi no yurai [The Origin of the Ridgepole of the Sanjūsangendō Temple], called "Kiyari bushi” [Treetugging song]. ${ }^{41}$ Significantly, in order to demonstrate this episode, Miura reenacted the singing, thereby introducing a piece of music that was completely unrelated to the opera itself.

Puccini-San asked me to sing something Japanese, so I sang from Sanjūsangendō: [she sings] "Wakano ura ni wa meisho ga gozaru, chin chin, yōi yōi yōi to na." Puccini-San liked the part that goes "yōi yōi" a lot and asked me to do it again. When I sang [she sings] "yōi yōi," PucciniSan played it on the piano and eventually a large piece of music was made out of it. I was asked to go upstairs for a meal, but Puccini-San's "yōi yōi" continued to ring through the house as great music. Later Puccini-San came upstairs and sat at the table, but he coughed and said "Io muoio," "I will die from this disease." 42

Apparently, Miura's performance captivated Puccini, who reacted enthusiastically and asked her to repeat a particular phrase she had sung. Puccini then began composing out new musical passages based on what Miura had provided. Miura's narrative here depicts a portrait of a composer who is lost deep in his creative process. At the same time, she emphasizes the significance of her role as a muse. However, by abruptly breaking in the middle of the recording and interpolating her performance of Puccini's Madama Butterfly with a spoken recollection and a performance of a traditional Japanese music, she places the importance her story above the narrative integrity of the opera. In the closing segment of her speech, Miura laments the premature death of the composer and pleads to her audience not to forget the accomplishments of Long and Puccini. Here too her motivation seems to be rooted in her desire not only to celebrate the greatness of these two creative artists but also to emphasize her own musical accomplishments. Miura asserts the significance of the two men by touting their positive impact on her career and, by extension, other Japanese singers who followed in her footsteps.

Although Miura's gesture disrupted the recording session of Puccini's Madama Butterfly, it suggests the singer's psychological identification with Cio-Cio-San that goes beyond her mimicking of the character's outer appearance. At the end of Act II, part 1, Cio-Cio-San prepares for what she believes to be the arrival of Pinkerton. The musical passage consists largely of previously explored musical materials presented in various states of development in novel combinations. Its placement within the narrative of the opera and its musical content suggest that this intermezzo not only depicts the passage of time but also Cio-Cio-San's recollection of past events. Significantly, at this precise moment in the narrative of the

\footnotetext{
41 "Kiyari bushi" is also known as "Kiyari uta," "Kiyari ondo," and simply "Kiyari." The play Sanjūsangendō munagi no yurai was written by Fuemi Wakatake and Akei Nakamura as Act III of a larger work, Gion nyogo kokonoe nishiki, which opened in 1760 at Toyotake-za in Osaka as a bunraku (ningyo jōruri) piece. For English-language synopses of Sanjüsangendō, see Samuel L. Leiter, New Kabuki Encyclopedia: A Revised Adaptation of “Kabuki jiten” (Westport, CT: Greenwood Press, 1997), 127; Shuzaburo Hironaga, Bunraku: Japan's Unique Puppet Theater (Tokyo: Tokyo News Service, 1964), 274-75; and A. Kimi Coaldrake, Women's Gidayū and the Fapanese Theatre Tradition (London: Routledge, 1997), 236-37.

${ }^{42}$ Miura, "Pucchīni no omoide $\sim$ Sanjūsangendō." Transcription and translation mine.
} 
opera-in which Cio-Cio-San revisits her memories of a happier time with Pinkerton-Miura inserts her own memories of performing Madama Butterfly around the world and meeting Puccini. Paradoxically, however, Miura's identification with Cio-Cio-San is so powerful at this point that her voice overwhelms Puccini's music. As such Madama Butterfly provided a valuable platform for Miura to present her original contribution designed to impact her legacy and reputation after her death.

When the recording session was over, Miura is said to have broken down in tears unable to bear the pains of coming to terms with her inability to sing the way she once did. ${ }^{43}$ Yet the recording was successful in the sense that it cemented the posthumous reputation of the singer as one of the pre-eminent specialists in the title role of Puccini's Madama Butterfly. The titles of Miura's autobiography edited by Yoshimoto and Takahashi's biography, respectively Ochō Fujin: Miura Tamaki ikō [Madam Butterfly: Unpublished Manuscript of Miura Tamaki] and Eien no Chōchō Fujin [The Eternal Madam Butterfly] both present Miura essentially as an embodiment of the fictional character of Madam Butterfly, incorporating the title of Puccini's opera in their own works. The title of Tanabe's biography, Kōshō Miura Tamaki [Investigation of Tamaki Miura], does not refer to the opera, but the illustration on the cover by Tetsuya Nagano presents a yellow and black butterfly hovering above a colorful kimono in a floral design.

\section{Remembering the Body and Voice of Miura}

Another recurring trope in narratives about Miura's final days is the comparison of her current physical state and vocal ability to those from her past. Repeatedly these documents ask their readers to recall Miura's corpulent body and her legendary ample voice from the past while reminding them that she no longer possessed either. This sense of loss appeared first in an article in Jiji Shimpō about Miura's final public recital on March 21. One of its first sentences reports that "the audience choked back tears as they heard her thin and painful voice and saw her terribly emaciated body on the stage, remembering the voluptuous figure she once possessed." ${ }^{\prime 4}$ The line at once captures the sense of shock and profound pity that visited those who saw and heard Miura in her final days. These obsessions with a prima donna's body and her voice, particularly her failing one, are, according to some scholars, frequently encountered features of diva biographies. Commenting on the challenge of assessing the voices of prima donnas before the age of recording, Mary Ann Smart observes that "it seems significant that what often does survive is a wealth of visual evidence: engravings, costumes designs, and portraits allow us to recover a sense of the body." 45 Terry Castle, in her essay on the mortality of prima donnas, points to the strong emotional reaction opera lovers have to the declining voice of their favorite singers. "Hearing a particular voice strike out with all its force," she writes, "can produce overwhelming joy and relief; the loss of such a voice, even when we do not understand the language it has been uttering, can be terrifying." ${ }^{46}$ Subsequent descriptions of Miura in Japanese newspapers repeatedly evoke the sentiment of loss and regret that the Jiji Shimpo article conveyed, but underlying these reports was, perhaps, the readers' terrifying realization of their own mortality.

For instance, in its article dating from April 7, Mainichi Shimbun, reports that Miura's weight had declined by half from about 150 to 75 pounds. A picture accompanying the article portrays the soprano sitting up in a bed flanked by a doctor to her right and a nurse to her left. Miura, wearing a hood, turns her

\footnotetext{
${ }^{43}$ Miura, Ochō Fujin, 244.

44 "Saigo no butai," Fiji Shimpō, March 23, 1946, 2.

${ }^{45}$ Smart, "The Lost Voice of Rosine Stoltz," 32.

${ }^{46}$ Terry Castle, "Breath's End: Opera and Mortality," in The Arts of the Prima Donna, 212.
} 
eyes away from the camera and looks down onto what appears to be a piece of paper in her hands. The doctor holds his hand toward the soprano as if to say he is ready to assist at any given moment, and the nurse gently places her hands on her shoulder overlooking the paper. Together the article and the photograph communicate Miura's strong determination to sing despite the visible deterioration of her body. Yet, Miura was unable to convince the author of the article who concludes the piece with a rueful contemplation:

Miura sings as the doctor holds her hand. The bracelet that once tightly wrapped her wrist is now about to fall off. Her voice is pitiful and low, but it still reminded the listener of her voluptuously ample voice unimaginable from a person of an advanced age of [sixty-two]. ${ }^{47}$

The convoluted closure to this article juxtaposes Miura's image and voice of the past with those of the present. The image of the bracelet falling off her arm vividly reminds the readers of Miura's weight loss. At the same time, the impression of her lackluster voice communicates the impossibility of the author's desire to recuperate Miura's voice-a voice that now only exists in his memory and is no longer accessible at the present moment.

The Japanese media's focus on Miura's deteriorating body reached a high point in the report of the autopsy of Miura's throat that appeared in the May 29 issue of Asahi Shimbun. The article states that although the soprano died at an advanced age, "the margins of her vocal folds remain beautifully straight like those of a young girl of twenty-two or twenty-three." 48 This account counters the widely circulating narratives of Miura's failed attempt to recuperate her voice by celebrating the youthfulness of an organ located deep within the interior of her body. Paradoxically, it was only in the act of autopsy that Miura's voice was able to transcend the limitations of her deteriorating body. ${ }^{49}$ Furthermore, the autopsy of Miura's throat recalls the manner in which Cio-Cio-San dies at the end of the opera where the stage directions instructs her to slit open her throat. ${ }^{50}$ As in previous examples of parallels between Miura and Cio-Cio-San reported in newspapers, there are no obvious signs that the author of the article recognizes the connection.

Miura too was keenly aware of the gap between what she was capable of doing physically at the recording session and what she would have wanted to accomplish, and conveyed her frustration through a candid admission of her inability to control her bodily functions. In her diary, Miura recalls the difficulties she experienced during the recording and regrets her failure to recover the voice she once possessed:

I was happy to be able to at least record my own Butterfly, but saddened because I was unable to sing with force or sustain high notes. Whenever I tried to sing a high note, I experienced incontinence. With the help of Mrs. Moriya, I used the toilet prepared for this purpose in the

\footnotetext{
47 “Omoide no 'Ochō Fujin,” Mainichi Shimbun, April 7, 1946, 2. The article states that Miura died at age sixty-three according to the traditional way of counting age that was still widely practiced in Japan at the time.

48 “Chittomo toshi toranu seitai: Tamaki-Joshi no inkō Tōdai de hozon" [The Vocal Folds That Do Not Age at All: Madam Tamaki’s Throat Preserved at the Tokyo University], Asahi Shimbun, May 29, 1946, 2.

49 This “discovery" seems to contradict Castle's statement that "Singers seem to live sadly accelerated lives: the 'youth' and 'freshness' and 'bloom' with which they being turn out to be, in the most cases, pathetically perishable qualities." Castle, "Breath's End," 210.

${ }^{50}$ Although Cio-Cio-San is often thought to commit the ritual disembowelment of hara-kiri or seppuku, the stage directions included in the published orchestral and piano-vocal scores directs her to mime the slitting of her throat. The stage directions immediately preceding Act II, part 2, Rehearsal Number 53 (p. 469), when she is about to pierce her throat before she sees her son Trouble, describes her placing "the dagger sideways on her throat" ("Si punta il coltello lateralente alla gola"). The actual act of stabbing takes place behind a screen, but when Cio-Cio-San reemerges on scene three measures before Rehearsal Number 57 (p. 480), she is seen with a "large white veil around her neck" ("il gran velo bianco le circonda il collo"), presumably used to hide her wound.
} 
corner of the room whenever I had a moment during the orchestra's intermezzos. ${ }^{51}$

Miura's biographer Yoshimoto picks up on this detail in his own recollection of the soprano. He remembers Miura collapsing into tears as soon as she completed the recording session. Once she had regained her composure, she explained her frustration: "I cannot even sing one percent of what I have in mind today. I cannot sing well at all when I feel like going to the bathroom whenever I sing forte. I am sad to think that such a bad recording of Madama Butterfly will remain the last recording of Tamaki Miura." ${ }^{~} 2$ These accounts convey the physical and mental anguish Miura herself experienced in coming to terms with the gap between her collapsing body and her persistent will to sing.

Considering the severe food shortage and lack of basic medical care that plagued many Japanese people in the period immediately after the conclusion of the war, the Japanese media's focus on Miura's body, especially her dramatic weight loss and illness, is not surprising. While most Japanese would have had a difficult time imagining the lavish lifestyle Miura had enjoyed at the height of her fame, they must have been intimately familiar with Miura's plight of hunger and disease at the end of her life. At the same time, the emphasis on Miura's body and voice appears to be a part of a larger trend in the Japanese postwar cultural landscape that literary critic Yoshikuni Igarashi analyzes in Bodies of Memory. According to Igarashi, Japanese survivors of the war perceived their bodies as "sites for national rehabilitation" that overcame the crisis brought about by their nation's defeat. ${ }^{53}$ Bodily metaphors were also used to explain the newly emerging political order, namely the collapse of the Japanese empire and Japan's alliance with the United States, but in an explicitly gendered manner. Having lost their control over their former colonial subjects, Japanese imagined their country adopting a feminized role in relation to the United States and their bond with their former enemy state in terms of the two nations' mutual desire for each other. ${ }^{54}$ Within this context, the description of Miura's beautifully preserved maidenly vocal folds may have functioned to express the desire of the Japanese public to project a redeeming quality of their nation, with an overtone of a symbolic national feminine purity, jealously guarded in the ruined body of the soprano.

\section{The Meanings of Miura's Death: Asahi Shimbun and Yukio Mishima}

Igarashi's reading of Japanese literature brings us to the third and final recurring theme in the postwar reception of Miura, which is to endow Miura's death with additional meanings about Japan's defeat in World War II. Here I present two case studies from what we might think of as two opposing political positions: a pair of articles that appeared in Asahi Shimbun, an editorial and the newspaper's signature column on topical issues "Tensei Jingo" [Heavenly Voice, Human Words] that appeared on the same issue on May 28, 1946, and a short story, "Chōchō," by the twenty-three-year-old Yukio Mishima, published in 1948. According to historian John Dower, during the Occupation, Asahi Shimbun printed articles that challenged its readers to reflect on the experience of the war and criticized the weaknesses in Japanese political organization, social structure, and even ethical foundation that led to the nation's defeat in the war as well as the crimes it committed against its colonial subjects and enemies. ${ }^{55}$ In its

\footnotetext{
${ }^{51}$ Miura, Ochō Fujin, 216.

${ }^{52}$ Ibid., 244.

${ }^{53}$ Yoshikuni Igarashi, Bodies of Memory: Narrative of War in Postwar Fapanese Culture, 1945-1970 (Princeton: Princeton University Press, 2000), 5.

${ }^{54}$ Ibid., 14

${ }^{55}$ John Dower, Embracing Defeat: Fapan in the Wake of World War II (New York: W.W. Norton \& Co., 1999), 494 and $506-507$.
} 
acknowledgment of the collective and individual Japanese responsibility of the atrocities of the war, the articles in Asahi Shimbun resonate with the attitude toward war memory adopted by what Philip A. Seaton identifies as the "progressive" group within Japan. ${ }^{56}$ After 1960, Mishima, on the other hand, wrote fictions that propagated his unique brand of right-wing, ultra-nationalist political and aesthetic ideology. ${ }^{57}$ Although his 1948 short story does not contain any overt nationalist or ultra-nationalist political message, it features a main character who was an officer of the Japanese Imperial Army. In "Chōchō" the shadow of the once-mighty Japanese Empire can be felt throughout the narrative. When the editor and the columnist of Asahi Shimbun and Mishima wrote about Miura's death, they imbued this momentous event with contradictory meanings that went beyond the passing of a famous artist, reflective of the dynamic cultural ferment of Occupied Japan.

The unnamed editor and the columnist of Asahi Shimbun not only mourned the passing of Miura but also lamented the lack of adequate appreciation among the Japanese, which, in turn, was conditioned by the imposition of the twisted, perhaps even "undemocratic," priorities that valued military achievements above artistic ones. In the editorial piece, the author compares the sorry farewell of Miura to that of the celebrated retirement speech of the world-famous Australian opera singer Nellie Melba. The author analyzes that the disadvantages that Miura faced in her home country at the end of her life were due to the lack of a knowledgeable public who could have "critiqued, admired, understood, and supported" her musical activities in Japan. Reading Miura's inability to find an attentive public as a political allegory, the author argues for the need of cultivating such a public not only for the advancement of the arts, but also so that a "democratic revolution" may take roots in Japan. ${ }^{58}$ The "Tensei Jingo" column, on the other hand, laments the death of Miura, as well as the lack of respect for artists and intellectuals in general compared to that bestowed upon military leaders, citing a comment made by the chief editor of the Chinese newspaper Ta Kung Pao. The author finds this lack problematic, especially in Japan's future development as a "peaceful nation of culture" [heiwa na bunka kokka]. ${ }^{59}$ The call for the embrace of democracy and peace exemplified in these articles also saturated the rest of Japanese media during the Occupation that the words themselves became, within few years, part of what John Dower calls the "talismanic language" of postwar Japan. ${ }^{60}$ Like the author of the editorial who compared the Japanese's soprano's relationship with her audience to the standard set by that of the Australian opera singer, the columnist draws on the insight of a Chinese intellectual, hailing from another victorious nation of the recent war, in his reflection and criticism of Japanese politics and culture. The authors of these articles use Miura's death as a starting point from which to subtly express their rejection of the militarism that dominated Japan before and during World War II and to criticize what they perceived to be the nation's stunted cultural development. But the tragedy also provided yet another opportunity for them to reinforce the progressive message of peace and democracy.

On the other hand, Mishima, in his short story "Chōchō," treats Miura's death mainly as an

\footnotetext{
${ }^{56}$ Philip A. Seaton, Japan's Contested War Memories: The "Memory Rifts” in Historical Consciousness of War War II (London: Routledge, 2007), 21-22.

${ }^{57}$ Susan J. Napier, "Death and the Emperor: Mishima, Ōe, and the Politics of Betrayal," The Fournal of Asian Studies 48, no. 1 (1989): 74. For considerations of Mishima's peculiar brand of nationalism and politics, see also Takehiko Noguchi, "Mishima Yukio and Kita Ikki: The Aesthetics and Politics of Ultranationalism in Japan," trans. Teruko Craig, The fournal of Fapanese Studies 10, no. 2 (1984): 437-54; and Roy Starrs, Deadly Dialectics: Sex, Violence, and Nihilism in the World of Yukio Mishima (Honolulu: University of Hawaii Press, 1994), 155-73.

58 “Geijutsuka no shi to 'kōshū"” [The Death of an Artist and the "Public"], Asahi Shimbun, May 28, $1946,1$.

59 “Tensei Jingo," Asahi Shimbun, May 28, 1946, 1.

${ }^{60}$ Dower, Embracing Defeat, 509.
} 
aesthetic event that encourages its readers to look backward in time rather than toward the future. The narrative, unfolding in three parts, freely intertwines events from Miura's final days with the lives of fictional characters, Kiyohara, a suave and debonair former officer of the Japanese Imperial Army and Hanako, his younger and slightly impetuous love interest, against the backdrop of the World War II and its aftermath. The first part of the short story opens with the depiction of Miura's final recital on March 21 deploying the narrative tropes encountered in biographical accounts about the soprano discussed earlier. Upon seeing the aged and emaciated Miura on stage for the first time after the war, Kiyohara reacts with shock and disappointment. He is dismayed to see the once-Rubenesque figure of the soprano reduced to a pitiable state. Yet, once he hears Miura sing, Kiyohara recognizes her exquisite voice that he had always admired:

When that incomparable pure voice, sounding almost possessed, sought to sing, she had to open her mouth against her will. Even if her body was decaying beneath the shadow of her voice, that voice remained like a face with everlasting flesh. When anyone hears her voice, he only sees that magnificent and beautiful mask.

$[\ldots]$

Suddenly Kiyohara imagined hearing the melody of "Un bel dì" that he loved in the past. Could this have been an association made possible by the mysterious ability of the skillful diva, who like a sorceress conjures up visions at will? ${ }^{61}$

In this passage, Mishima draws a sharp contrast between Miura's decaying body and her "incomparable pure voice," which seems to exist on a metaphysical plane with a will independent from Miura's person. Furthermore, Miura's voice seems to possess the power to control Kiyohara's perception of reality. He hears, in the middle of the performance of Schubert's Die schöne Müllerin, a strain from Puccini's Madama Butterfly.

The passage also suggests that, because the audience members' identification of Miura with the character of Cio-Cio-San is so firm, even when Miura sang music unrelated to Puccini, listeners such as Kiyohara are reminded of Puccini's opera. Kiyohara's account of Miura's recital concludes with a memorable, if slightly grotesque and macabre, depiction of the prima donna as a gigantic butterfly.

And when I witnessed the garish figure of Madam Miura exiting, I could only see the image of a dying butterfly. She wandered around the stage aimlessly spraying her glittery powder everywhere and flapping her brilliant wings, whose miserable tears she no longer knew how to cover up. The placid ocean was shining in her large but dead blue eyes. Every time she raised her antennas, they drooped as if on their own accord, leaving behind a sense of emptiness. And the butterfly finally collapsed as she experienced the shiver of death that visited her in rippling waves. $^{62}$

The association Kiyohara makes here between Miura and Cio-Cio-San's namesake insect conveys the protagonist's sense of awe at witnessing the prima donna's extraordinary, perhaps even monstrous, attempt to transcend the physical limitations of her decaying human body. The hero, therefore, sees in Miura's dying performance something marvelous, a miserable but at the same time sublime display of the passing of a once-beautiful body and a magical voice that recalled a happier, more prosperous time in the past. As such, Mishima's depiction of the final performance of Miura projects a faint but distinct longing for a bygone era, representing the aestheticized collapse of the Japanese Empire.

\footnotetext{
${ }^{61}$ Mishima, "Chōchō," 13.

${ }^{62}$ Ibid., 16.
} 
This extraordinary experience triggers, in Kiyohara's mind, a memory of Miura's voice singing "Un bel dì" before to the war and prompts him to write a lengthy letter to his love interest Hanako, which constitutes the middle portion of the short story. In this letter, Kiyohara reminds Hanako of their chance encounter in Milan and Miura's performance of Madama Butterfly at La Scala they witnessed together. In the concluding section, Kiyohara reunites with Hanako at a ball held at the house of a Japanese aristocrat some months after Miura's recital. The two had been separated during the war due to Kiyohara's assignment in Taiwan; however, unlike Pinkerton, Kiyohara discovers that his love interest had married a Japanese nobleman while he was stationed abroad. It is here that Mishima reveals Kiyohara's deception: the events he had recounted in the letter turn out to be entirely made up. In fact, neither Kiyohara nor Hanako have ever visited Milan. Hanako even reproaches Kiyohara for making her too old in the letter. (The actual age difference between the two would have made her a mere child when Kiyohara claims to have visited Italy and met her there.) The two briefly talk about the recent death of Miura, and discover that they were both present at Miura's final performance. Suddenly, Hanako changes the subject of their conversation and breaks into a monologue explaining her inability to wait for Kiyohara during the war. She had become bored at staring at the ocean day in and day out. The story concludes ruefully a month after their reunion when Kiyohara receives the news of the sudden passing of Hanako from tuberculosis.

Mishima's presentation of Kiyohara initially resembles that of Puccini's depiction of Pinkerton. The two men share similar military occupations and leave behind young Japanese lovers while they are stationed away from Japan. The racial difference that exists between Pinkerton and Cio-Cio-San is obviously lacking in the pairing that Mishima presents. However, by having Kiyohara reside in Taiwan during the war, Mishima renders Kiyohara a representative of modern Japanese imperialism. The long letter Kiyohara addresses to Hanako too seems to allude to the letter that Pinkerton has Sharpless read aloud, unsuccessfully, to Cio-Cio-San. Yet the parallel ends here. Hanako, unlike Cio-Cio-San who resists the advance made by Prince Yamadori during Pinkerton's absence, ends up marrying a Japanese nobleman, Count Kawaramachi. It is Kiyohara not Hanako who, at the end of the story, turns out to be the rejected lover. Kiyohara's amounts to his wishful fantasy, a trite and ineffectual rewriting of the past, reminiscent of the way in which Cio-Cio-San imagines a wishful future of happiness in "Un bel dì." Toward the conclusion of the short story, Kiyohara leaves the ballroom and stands outside on the veranda facing the harbor. Hanako's new husband tells him that the ocean is now visible because the American bombing of the city opened up the view. From that vantage point, Kiyohara sees, like Cio-Cio-San had done before him, an American ship anchored on the calm, blue water. The metamorphosis of the butterfly is complete: Kiyohara, who once may have fancied himself as a Japanese Pinkerton, now understands himself as occupying the position of Cio-Cio-San.

Mishima's revelation of Kiyohara's ultimate status as Cio-Cio-San at the conclusion of his short story echoes Japan's gendered position in the postwar international order. In her monograph, America's Geisha Ally, historian Naoko Shibusawa demonstrates how US government officials, soldiers and civilians, news media, and Hollywood artists, compared the relationship between the US and the Japan to that between an adult and a child or a man and a woman. Such easy-to-grasp and non-threatening analogies enabled many Americans to accept the sudden policy change made by the US government to rehabilitate the former enemy into a crucial and staunch ally in the early phase of the Cold War. ${ }^{63}$ Mishima's short

\footnotetext{
${ }^{63}$ Naoko Shibusawa, America's Geisha Ally: Reimagining the Fapanese Enemy (Cambridge: Harvard University Press, 2006). The analogy of the postwar US-Japanese relationship as a male-female relationship is also proposed in Igarashi, Bodies of Memory, 14; and Mire Koikari, Pedagogy of Democracy: Feminism and the Cold War in the U.S. Occupation of Japan (Philadelphia:
} 
story in which a once-proud Japanese army officer realizes his sorry fate as a latter-day Cio-Cio-San suggests that such gendered comparison between the US and Japan also circulated among Japanese as well. Furthermore, Kiyohara's fabrication of an alternate history between him and Hanako can be understood as an antidote to the threat of the erasure of his masculinity, a way for Kiyohara to escape into a fantasy about the past in order to cope with the difficult realities of the present. Kiyohara's penchant to rewrite the past reemerges in Mishima's mature narratives with overt nationalist messages such as "Yūkoku" (1961) and Homba (1969), in which the author presents alternate versions of Japanese history. According to Susan J. Napier, these works are Mishima's "conscious attempt to recover and transcend history by rewriting it." 64 On November 25, 1970, Mishima committed a highly-publicized seppuku, ritual suicide by disembowelment, after attempting and failing to persuade the members of Japan's Self-Defense Forces to effect a coup d'état to restore Japan's ancient imperial political order. Ultimately, Mishima's penchant for rewriting the past culminated in, according to Igarashi, "a tragedy through his own death." ${ }^{65}$ Here, too, the echo of Cio-Cio-San's death is perceptible.

Although both engaging with the death of Miura, the messages that the editor and the columnist of Asahi Shimbun and Mishima present in their writings diverge drastically. Asahi Shimbun's analysis of Miura's sad demise positions it as a logical consequence of Japan's undemocratic wartime priorities. They use Miura's death as a warning against the mistakes Japan committed in the decades leading up to and during the war. If the authors show regret, they do not regret that Japan lost the war but that the Japanese people were not able to achieve the level of cultural and political sophistication that would have supported Miura and, they believed, would have prevented them from spiraling down the destructive path of war. Mishima, on the other hand, found meaning in Miura's death itself. There is something inevitable and fatalistic about his depiction of Miura. This is not to say that Kiyohara does not express any regret, but rather his desire to alter the past becomes a valuable creative impetus for him. After all, in the conclusion of the story, Kiyohara, the character representing the wartime Japanese militarism come out relatively unscathed while Hanako dies unexpectedly.

\section{Butterflies on the Streets}

The three recurring motifs in narratives about Miura that permeate these sources are the identification of Miura with the character of Cio-Cio-San from Puccini's Madama Butterfly, the juxtaposition of past and present through Miura's body and voice, and the overlapping of Miura's life and death with the destiny of Japan and its people. One contemporary topic of discussion that would have been on the surface of the Japanese consciousness at the time that brings all three of these motifs together is the institutional prostitution that emerged in the early days of the Occupation. The phenomenon was part of a larger pattern of contradictory gender and sexual politics of the Occupation. One of the lasting political impacts of the Occupation was the guarantee of gender equality that was written into the postwar Japanese constitution resulting in Japanese women's right to vote and run for political office for the first time in history. American women working for the Occupation, most notably Beate Sirota Gordon (19232012) who played a crucial role in the constitutional revision, spearheaded many of the gender reforms

Temple University Press, 2008), 17-18.

${ }^{64}$ Napier, "Death and the Emperor," 73.

${ }^{65}$ Igarashi, Bodies of Memory, 181. 
throughout the country, often in collaboration with local women's organizations. ${ }^{66}$ However, while promoting gender parity, the leaders of the Occupation saw the new postwar alliance between the US and Japan in gendered terms, resembling that of the traditional patriarchal unequal relationship between a man and a woman. ${ }^{67}$ Furthermore, the various reforms regarding gender equality were often based on Orientalist notions about race and ethnicity that, in Koikari's words, "reinscribed the racialized imperial notions of American superiority and Japanese inferiority." ${ }^{68}$ The official and unofficial sexual trafficking of Japanese women in the early days of the Occupation was another manifestation of the complex negotiation of power among the various contingents within the Occupation and in Japan. While Miura's radio performance of Madama Butterfly and her own widely publicized death brought Puccini's opera to the airwaves and the printed pages of newspapers, the story of Cio-Cio-San and Pinkerton was effectively reproduced on a massive scale in the streets of Japan. ${ }^{69}$

Within days of the announcement of Japan's unconditional surrender to the Allied Powers, Japanese government officials began instructing law enforcement agencies to set up special establishments to serve the sexual needs of the conquering soldiers. Through such a measure, Japanese political leaders attempted to minimize the kinds of brutal sex crimes Japanese soldiers had committed during the war that they feared Allied troops would inflict on Japanese women. ${ }^{70}$ By one estimate, there were about 20,000 women working throughout the nation in the state-run prostitution establishments, euphemistically known as the Recreation and Amusement Associations (RAA), by the end of $1945 .^{71}$ Despite its popularity, the Occupation authority directed the Japanese government to outlaw public forms of prostitution in January 1946, claiming that the practice ran counter to its democratic principles. In the meantime, private, decentralized forms of prostitution thrived and became more visible to the public eye. A class of women who serviced American GIs, known as pan-pan and Baby-San, emerged. The prostitutes quickly became a potent symbol of occupation in the popular imagination. Among the GIs, pan-pans who formed monogamous relationship were known as "onlys," while those who flittered among various customers were called, ironically, "butterflies."72

Responding to the pressure within the Occupation government, MacArthur himself introduced anti-fraternization regulations designed to prohibit sexual relationships between American soldiers and Japanese women. ${ }^{73}$ Privately, however, MacArthur thought differently about the situation. His aide Major Faubion Bowers recalls MacArthur complaining that "they keep trying to get me to stop all the Madame Butterflying around." ${ }^{74}$ Here the Supreme Commander for the Allied Forces himself invoked the title of Puccini's opera as a cipher for the sexual liaisons between American soldiers and Japanese women. Despite these regulations, bi-national coupling did continue, and, by the summer of 1946, shortly after the death of

\footnotetext{
${ }^{66}$ Koikari, Pedagogy of Democracy, 32-74.

${ }^{67}$ See note 68.

${ }^{68}$ Koikari, Pedagogy of Democracy, 16.

${ }^{69}$ Brian Burke-Gaffney observes that, "in the case of Madama Butterfly, there was indeed an uncanny similarity between the scenes unfolding on stage and the Allied Occupation.” Burke-Gaffney, Starcrossed, 167.

${ }^{70}$ Yuki Tanaka, Japan's Comfort Women: Sexual Slavery and Prostitution During World War II and the US Occupation (London: Routledge, 2002), 133.

${ }^{71}$ Eiji Takemae, Inside GHQ: The Allied Occupation of Japan and Its Legacy (London: Continuum, 2002), 68. Takemae further states that the "RAA was a domestic version of the extensive military brothel system that is thought to have ensnared between 80,000 and 100,000 Asian women (and possibly many more) to serve Japanese troops during the war" (69).

${ }^{72}$ Dower, Embracing Defeat, 123-39; Shibusawa, America's Geisha Ally, 34-47.

${ }^{73}$ Yukiko Koshiro, Trans-Pacific Racisms and the U.S. Occupation of Fapan (New York: Columbia University Press, 1999 ), 60. Marriages between American GIs and Japanese women were not legally recognized until 1948.

${ }^{74}$ Takemae, Inside GHQ, 79-80.
} 
Miura, the first group of mixed-race children born out of these illegitimate unions became widely recognized. Despite the visible signs of inter-racial fraternization, the occupation authority imposed strict censorship rules on Japanese print and broadcast media suppressing the coverage of liaisons between Japanese women and American men as well as discussion of their mixed race children. ${ }^{75}$ It is therefore startling to find out that the Occupation authority permitted Miura's broadcast of an opera that deals with the tragic fate of a Japanese geisha who suffers from the cruel promise of an American naval officer and bears his child. ${ }^{76}$

In fact, rather than shying away from Puccini's opera, the Occupation authority seems to have encouraged and promoted the reinstitution of Madama Butterfly on the Japanese stage. Takahashi, a concert promoter who worked closely with Miura in the final months of her life, recalls meeting a JapaneseAmerican member of the occupation army to discuss the possibility of arranging a staged performance of the opera featuring the famed soprano. ${ }^{77}$ The NHK, which was also under the supervision of the occupation authority, programed an excerpt from Madama Butterfly as early as December 1, 1945, four months prior to Miura's broadcast. ${ }^{78}$ The occupation authority also negotiated the rights to perform Gilbert and Sullivan's Mikado for the opera company run by another Japanese soprano, Miho Nagato, and may also have influenced their decision to stage The Old Maid and the Thief by the Italian-born American composer Gian Carlo Menotti, which contains a spinster woman called Miss Pinkerton. ${ }^{79}$ Although a systematic analysis of the Occupation's propagandistic use of Madama Butterfly and other Orientalist works is beyond the scope of this article, it seems clear that the Americans too saw some value in promoting Puccini's opera in Japan. ${ }^{80}$

However, that Puccini's Madama Butterfly seems to have functioned, to some extent, as a blueprint for American soldiers' interactions with the local Japanese population demonstrates the objections made by many critics against the opera for its negative impacts on the lives of people, especially women, of Japanese and other Asian backgrounds. ${ }^{81}$ This reification of the opera's symbolic subjugation of Japanese people under Westerners is the more striking considering that when the opera was first performed in 1904, Japan was a rapidly expanding military and colonial power in East Asia. Although often considered to be an archetypal work of Orientalist fantasy that reflects and reinforces the asymmetrical political power dynamics between the West and the East, some have argued that the ideology the opera projected initially

\footnotetext{
${ }^{75}$ Ibid., 387; and Koshiro, Trans-Pacific Racisms, 66. Toward the very end of the Occupation, in 1951, American reporter Peter Kalischer published a long article on this topic in the magazine Collier's entitled "Madame Butterfly's Children.” BurkeGaffney, Starcrossed, 168.

${ }^{76}$ For instance, the concerns over the "miscegenation angle" in the opera prompted the filmmakers from Paramount Pictures to underplay signs of Pinkerton's awareness of his child with the Japanese geisha in its 1932 film Madame Butterfly. W. Anthony Sheppard, "Cinematic Realism, Reflexivity and the American 'Madame Butterfly' Narratives," Cambridge Opera Fournal 17, no. 1 (2005): 79.

77 Takahashi, Eien no Chōchō Fujin, 183-87.

${ }^{78}$ NHK bangumi kakuteihyō / rajio.

${ }^{79}$ Burke-Gaffney, Starcrossed, 167; and Masui, Nihon operashi, 343 and 349.

${ }^{80} \mathrm{On}$ this point, the fortunes of Madama Butterfly may parallel that of the products of American popular culture, especially jazz. See, for example, Atkins, Blue Nippon. The promotion of American musicians and their works in both jazz and classical music continued in Japan after the Occupation as part of US Cold War cultural diplomacy. See Danielle Fosler-Lussier, Music in America's Cold War Diplomacy (Oakland: University of California Press, 2015) and Fumiko Fujita, Amerika bunka gaikō to Nihon: Reisenki no bunka to hito no kōryū [US Cultural Diplomacy and Japan in the Cold War Era], (Tokyo: Tōkyō Daigaku Shuppankai, 2015).

${ }^{81}$ Karen Ma, The Modern Madame Butterfly: Fantasy and Reality in Japanese Cross-cultural Relationships (Rutland, VT: Charles T. Tuttle, 1996); Dorinne Kondo, About Face: Performing Race in Fashion and Theater (New York: Routledge, 1997); and Susan McClary, "Mounting Butterfly," in A Vision of the Orient: Texts, Intertexts, and Contexts of Madame Butterfly, ed. Jonathan Wisenthal et al. (Toronto: University of Toronto Press, 2006), 21-35.
} 
resonated with the perceived threat that Japan imposed on the Western powers. ${ }^{82}$

Miura's involvement in Puccini's Madama Butterfly during the Occupation can be understood, therefore, as another demonstration of Orientalism's overwhelming power to compel and coerce the participation of a Japanese subject in its realization. Yet to judge Miura's performance in this light would also negate the creative power that the prima donna obviously held during the course of her performance on and off the stage. After all, Miura, not only at the end of her life but throughout her career, expended a considerable amount of energy erasing, or at least minimizing, the stigma of foreignness in the opera for her Japanese audience members by framing her performance of Cio-Cio-San as an authentic expression of her Japanese identity. Furthermore, the aura of tragedy and pathos that surrounded the coverage on the end of Miura's life, and the near-eradication of the figure of Pinkerton from her final performance of Madama Butterfly, helps to reposition the character of Cio-Cio-San as a genuinely tragic figure rather than a mere Orientalist caricature of a Japanese woman.

For the Japanese press, discussing Madama Butterfly through Miura's performance was perhaps also a way to tacitly acknowledge the sexual trafficking of Japanese women which they were unable to communicate directly due to Occupation censorship. However, Miura's recording of Madama Butterfly excluded Pinkerton from the narrative of the opera and focused on the tragic demise of Cio-Cio-San, thereby conditioning the reception of the opera in Japan to focus on the emotional plight of the heroine. If the narrative of Madama Butterfly reminded people of the actual sexual relationships that were taking place between the American GIs and Japanese women, Miura's rendition of the opera and her own dramatic behavior taught the Japanese not only to pity the fate of Cio-Cio-San, but also to admire her dignity in the face of extreme physical and psychological adversities. At the same time, by obscuring the harsh realities of the Occupation with a purely aesthetic event, Miura's promotion of Madama Butterfly may have also prevented her audience members from scrutinizing the structural problems within Japanese society that forced tens of thousands of women to turn to prostitution to survive and support themselves and their families. ${ }^{83}$

Finally, the equation of Japan with the dying Miura, and by extension with Cio-Cio-San, also put the Japanese people squarely in the position of the victim. Such a stance prevented Miura and Japanese commentators from dwelling much on the atrocities their countrymen had perpetrated outside of and within Japan toward non-Japanese populations and each other during the war. The overlapping tales of Miura, Cio-Cio-San, and Japan, therefore, captured the inwardly-focused sense of shame, regret, and victimization shared by many Japanese during the early stages of the Occupation. At the same time, Miura's renewed engagement with Madama Butterfly symbolized a renewed embrace toward

\footnotetext{
${ }^{82}$ For analyses of the relationship between the opera and Japan's colonial aggression, see Jeremy Tambling, Opera and the Culture of Fascism (Oxford: Clarendon Press, 1996), 138-58; Richard Cavell, "Madama Butterfly and the Absence of Empire," in $A$ Vision of the Orient, 155-69; Jann Pasler, "Political Anxieties and Musical Reception: Faponisme and the Problem of Assimilation," in Madama Butterfly: L'orientalismo di fine secolo, l'approccio pucciniano, la ricezione: atti del convegno internazionale di studi, Lucca-Torre del Lago, 28-30 maggio 2004, ed. Arthur Groos and Virgilio Bernardoni (Florence: Leo S. Olschki, 2008), 17-53; and Domingos de Mascarenhas, "Beyond Orientalism: The International Rise of Japan and the Revisions to Madama Butterfly," in Art and Ideology in European Opera: Essays in Honour of Fulian Rushton, ed. Rachel Cowgill, David Cooper, and Clive Brown (Woodbridge, UK: Boydell Press, 2010), 281-302. In his recent monograph, Ralph Locke also provides a reading of the opera that complicates the perception of the opera as an exotic work. Ralph P. Locke, Musical Exoticism: Images and Reflections (Cambridge: Cambridge University Press, 2009), 202-13.

${ }^{83}$ This does not mean, however, that the Japanese people were oblivious to such concerns. Dower points to two journalistic pieces about Japanese prostitutes, one reported in the Mainichi Shimbun on September 29, 1946, and another on a radio program in April 1947, that "gave prostitution a face in occupied Japan." Both came well after the final broadcast and death of Miura. Dower, Embracing Defeat, 123-24.
} 
cosmopolitanism and a commitment toward the cultivation of peaceful cultural life. Both of these were, in fact, widespread sentiments among many Japanese, according to Dower, Seaton, and others, that emerged almost immediately after the conclusion of the war with the approval of the Occupation authority. ${ }^{84}$ Miura's final recording of Puccini's Madama Butterfly also contributed to the formation of this particular form of memory in Occupied Japan. The widespread media attention at the end of her life provided Miura with an opportunity to exert some control over her legacy. Even when her vocal instruments could not do justice to her lifelong achievements, this perceived lack turned out to trigger memories in her audience's mind that enhanced her stature in their eyes. At the same time, Miura's painfully public struggles with her illness prompted them to cast a backward glance on their own past experiences.

\section{References}

“\$75,000 for Red Cross at Theatrical Benefit: Kaiser’s Gold Cup, Auctioned for \$23,000.” New York Times, May 28, 1918, 8.

Atkins, E. Taylor. Blue Nippon: Authenticating Jazz in Japan. Durham, NC: Duke University Press, 2001. https://doi.org/10.1215/9780822380030.

Burke-Gaffney, Brian. Starcrossed: A Biography of Madame Butterfly. Norwalk, CT: EastBridge, 2004.

Buruma, Ian. The Wages of Guilt: Memories of War in Germany and Japan. New York: Farrar, Straus \& Giroux, 1994.

"Byōku o oshite Ochō Fujin; Miura Tamaki-San ga AK no maiku e" [Pushing through despite Her Ailing Body for Madam Butterfly; Mrs. Tamaki Miura in Front of the Microphone at AK]. Tōkyo Shimbun, April 12, 1946, 2.

Castle, Terry. "Breath's End: Opera and Mortality." In The Arts of the Prima Donna, 206-13.

Cavell, Richard. "Madama Butterfly and the Absence of Empire." In A Vision of the Orient, 155-69.

Chapman, John Griffin. "The Re-Education of the Japanese People.” EdD diss., University of Houston, 1954.

"Chittomo toshi toranu seitai: Tamaki joshi no inkō Tōdai de hozon" [The Vocal Folds That Do Not Age at All: Madam Tamaki's Throat Preserved at the Tokyo University]. Asahi Shimbun, May 29, 1946, 2.

Chiyo, Uno. "Miura Tamaki no henrin” [Fragment of Tamaki Miura]. In Wakaremo tanoshi, 246-84. Tokyo: Shūeisha, 1991.

Coaldrake, A. Kimi. Women's Gidayū and the Japanese Theatre Tradition. London: Routledge, 1997.

Cowgill, Rachel and Hilary Poriss, eds. The Arts of the Prima Donna in the Long Nineteenth Century. Oxford: Oxford University Press, 2012.

Dower, John W. Embracing Defeat: Japan in the Wake of World War II. New York: W.W. Norton \& Co., 1999.

Fosler-Lussier, Danielle. Music in America's Cold War Diplomacy. Oakland: University of California Press, 2015. https://doi.org/10.1525/california/9780520284135.001.0001.

\footnotetext{
${ }^{84}$ Dower, Embracing Defeat, 485-521; and Seaton, Fapan's Contested War Memories, 38-42. For further discussion on the controversial issue of the memory of World War II in Japan, see Ian Buruma, The Wages of Guilt: Memories of War in Germany and Fapan (New York: Farrar, Straus \& Giroux, 1994); George Hicks, Fapan's War Memories: Amnesia or Concealment? (Brookfield, VT: Ashgate, 1997); and Takashi Yoshida, From Cultures of War to Cultures of Peace: War and Peace Museums in Japan, China, and South Korea (Portland, ME: MerwinAsia, 2014).
} 
Fujita, Fumiko. Amerika bunka gaikō to Nihon: Reisenki no bunka to hito no kōryū [U.S. Cultural Diplomacy and Japan in the Cold War Era]. Tokyo: Tōkyō Daigaku Shuppankai, 2015.

"Geijutsuka no shi to 'kōshū"” [The Death of an Artist and the "Public"]. Asahi Shimbun, May 28, 1946, 1.

Groos, Arthur. "Return of the Native: Japan in Madama Butterfly/Madama Butterfly in Japan." Cambridge Opera Journal 1, no. 2 (1989): 167-194. https://doi.org/10.1017/S0954586700002950.

"Hanayaka ni Miura Tamaki-San ongakusō" [The Brilliant Musical Funeral of Mrs. Tamaki Miura]. Yomiuri Shimbun, June 8, 1946, 2.

Hicks, George. Japan's War Memories: Amnesia or Concealment? Brookfield, VT: Ashgate, 1997.

Hironaga, Shuzaburo. Bunraku: Japan's Unique Puppet Theater. Tokyo: Tokyo News Service, 1964.

Hosokawa, Shuhei. "Nationalizing Chō-Chō-San: The Signification of 'Butterfly Singers' in a JapaneseBrazilian Community.” Japanese Studies 19, no. 3 (1999): 253-68.

Igarashi, Yoshikuni. Bodies of Memory: Narrative of War in Postwar Japanese Culture, 1945-1970. Princeton: Princeton University Press, 2000.

Keiji Masui, Keiji. Nihon operashi, 1952 [History of Opera in Japan, -1952]. Tokyo: Suiyōsha, 2003.

"Kōkashu o eta sakkyokuka Pu-Shi Tamaki-Fujin o yorokobi mukau" [Composer Mr. P. Who Gained an Excellent Singer Gladly Welcomes Madam Tamaki]. Tōkyō Asahi Shimbun, April 25, 1920.

Koikari, Mire. Pedagogy of Democracy: Feminism and the Cold War in the U.S. Occupation of Japan. Philadelphia: Temple University Press, 2008.

Kondo, Dorinne. About Face: Performing Race in Fashion and Theater. New York: Routledge, 1997.

Koshiro, Yukiko. Trans-Pacific Racisms and the U.S. Occupation of Japan. New York: Columbia University Press, 1999.

Lancefield, Robert C. "Hearing orientality in (white) America, 1900-1930." PhD diss., Wesleyan University, 2004

Leiter, Samuel L. New Kabuki Encyclopedia: A Revised Adaptation of "Kabuki jiten.” Westport, CT: Greenwood Press, 1997.

Locke, Ralph P. Musical Exoticism: Images and Reflections. Cambridge, Cambridge University Press, 2009.

Ma, Karen. The Modern Madame Butterfly: Fantasy and Reality in Japanese Cross-cultural Relationships. Rutland, VT: Charles T. Tuttle, 1996.

Mascarenhas, Domingos de. "Beyond Orientalism: The International Rise of Japan and the Revisions to Madama Butterfly." In Art and Ideology in European Opera: Essays in Honour of Julian Rushton, edited by Rachel Cowgill, David Cooper, and Clive Brown, 281-301. Woodbridge, United Kingdom: Boydell Press, 2010.

McClary, Susan. "Mounting Butterfly," in A Vision of the Orient, 21-35.

Mishima, Yukio. "1946 nen 3 gatsu 21 nichi yū no Miura Tamaki dokushōkai" [Solo Recital by Tamaki Miura on the Evening of March 21, 1946]. In Hyōron 1 [Essays 1]. Vol. 26 of Mishima Yukio zenshü [Complete Works of Yukio Mishima: Definitive Edition], 570-71. Tokyo: Shinchōsha, 2003.

__. "Chōchō" [Butterfly]. In Tanpen shōsetsu 3 [Short Stories 3]. Vol. 17 of Mishima Yukio zenshū, 1130. Tokyo: Shinchōsha, 2002.

Miura, Tamaki. "Utaitsutsu sekai o meguru" [Traveling the World while Singing]. Shinshōsetsu 27, no. 6 (1922): 1-26. 
—. Densetsu no purima Miura Tamaki: debyūban kara saigo no rokuon made [The Legendary Prima Donna Miura Tamaki: From the Debut Disc to the Last Recording]. Vintage SYC-1001. CD. 1993.

Miura Tamaki zenshū: Botsugo 50nen kinen [The Complete Works of Tamaki Miura:

Commemorating the Fiftieth Anniversary of Her Death]. Columbia COCA-12424 - 28. CD. 1995.

. Miura Tamaki: Ochō Fujin [Tamaki Miura: Madam Butterfly]. Edited by Yoshimoto Akimitsu.

Ningen no kiroku 27. Tokyo: Nihon Tosho Sentā, 1997.

Miyasawa, Duiti. “Tamaki Miura and Puccini.” Opera News. December 10, 1956.

“Mme. Miura Dead: Japanese Singer.” New York Times, May 27, 1946, 16.

Napier, Susan J. "Death and the Emperor: Mishima Ōe, and the Politics of Betrayal." The Journal of Asian Studies 48, no. 1 (1989): 71-89. https://doi.org/10.2307/2057665.

NHK bangumi kakuteihyō / rajio [NHK Confirmed Scheduled of Programs / Radio]. September 1945 through December 1949. NHK Museum of Broadcasting, Tokyo. CD-ROM.

Noguchi, Takehiko. "Mishima Yukio and Kita Ikki: The Aesthetics and Politics of Ultranationalism in Japan.” Translated by Teruko Craig. The Journal of Japanese Studies 10, no. 2 (1984): 437-54. https://doi.org/10.2307/132145.

"Ōini utau Miura Tamaki-San: Beigunhei ian no ongaku kai de" [Mrs. Tamaki Miura Sings Greatly: At the Concert for Entertaining American Soldiers]. Yomiuri Shimbun, October 11, 1945, 2.

"Omoide no Ochō Fujin: Byōshō ni utau Miura Tamaki-San" [Madam Butterfly of Her Memories: Mrs. Tamaki Miura Singing at Her Sickbed]. Mainichi Shimbun, April 7, 1946, 2.

Pasler, Jann. "Political Anxieties and Musical Reception: Japonisme and the Problem of Assimilation." In Madama Butterfly: L'orientalismo di fine secolo, l'approccio pucciniano, la recezione: atti del convegno internazionale di studi, Lucca-Torre del Lago, 28-30 maggio 2004, edited by Arthur Groos and Virgilio Bernardoni, 17-53. Florence: Leo S. Olschki, 2008.

Poriss, Hilary. Changing the Score: Arias, Prima Donnas, and the Authority of Performance. Oxford: Oxford University Press, 2009. https://doi.org/10.1093/acprof:oso/9780195386714.001.0001.

__ . "Prima Donnas and the Performance of Altruism." In The Arts of the Prima Donna, 42-60.

Postlewait, Thomas. "Autobiography and Theatre History." In Interpreting the Theatrical Past: Essays in Historiography of Performance, edited by Thomas Postlewait and Bruce A. McConachie, 248-72. Iowa City: University of Iowa Press, 1989.

__ . "Theatre Autobiographies: Some Preliminary Concerns for the Historian." Assaph C 16 (2000): $157-72$.

Puccini, Giacomo. Madama Butterfly. Milan: Ricordi, 1999.

"Saigo no butai: Tamaki-San to chōshū namida no gasshō" [The Final Stage: Tamaki-San and the Audience in a Chorus of Tears]. Jiji Shimpō, March 23, 1946, 2.

Seaton, Philip A. Japan's Contested War Memories: The "Memory Rifts" in Historical Consciousness of World War II. London: Routledge, 2007.

Sheppard, W. Anthony. "Cinematic Realism, Reflexivity and the American 'Madame Butterfly' Narratives." Cambridge Opera Journal 17, no. 1 (2005): 59-93. https://doi.org/10.1017/S0954586705001941.

Shibusawa, Naoko. America's Geisha Ally: Reimagining the Japanese Enemy. Cambridge: Harvard University Press, 2006. 
Smart, Mary Ann. “The Lost Voice of Rosine Stoltz.” Cambridge Opera Journal 6, no. 1 (1994): 31-50. https://doi.org/10.1017/S0954586700004122.

Starrs, Roy. Deadly Dialectics: Sex, Violence, and Nihilism in the World of Yukio Mishima. Honolulu: University of Hawaii, 1994.

Takahashi, Iwao. Eien no Chōchō Fujin: Miura Tamaki [The Eternal Madam Butterfly: Tamaki Miura]. Tokyo: Shunjūsha, 1995.

Takemae, Eiji. Inside GHQ: The Allied Occupation of Japan and Its Legacy. New York: Continuum, 2002.

Tambling, Jeremy. Opera and the Culture of Fascism. Oxford: Clarendon Press, 1996.

Tanabe, Hisayuki. Kōshō Miura Tamaki [Investigation of Tamaki Miura]. Tokyo: Kindai Bungeisha, 1995.

Tanaka, Yuki.Japan's Comfort Women: Sexual Slavery and Prostitution During World War II and the US Occupation. London: Routledge, 2002.

“Tensei Jingo.” Asahi Shimbun, May 28, 1946, 1.

Wasserman, Michel. Le tour du monde en deux mille "Butterfly." L'Isle-sur-la-Sorgue, France: Le Bois d'Orion, 2000.

White, Kimberly. “Autobiographical Voices: Singers' Memoirs in fin-de-siècle France.” Paper presented at the $4^{\text {th }}$ Biennial North American Conference on Nineteenth-Century Music, Merrimack College, July 16-18, 2015.

Wisenthal, Jonathan, Sherrill Grace, Melinda Boyd, Brian McIlroy, Vera Micznik, eds. A Vision of the Orient: Texts, Intertexts, and Contexts of Madame Butterfly. Toronto: University of Toronto Press, 2006. https://doi.org/10.3138/9781442670532-003.

Yōgaku hōsō kiroku [Record of Western Music Broadcast] (April-May 1946). NHK Museum of Broadcasting, Tokyo.

Yoshida, Takashi. From Cultures of War to Cultures of Peace: War and Peace Museums in Japan, China, and South Korea. Portland, ME: MerwinAsia, 2014.

Yoshihara, Mari. "The Flight of the Japanese Butterfly: Orientalism, Nationalism, and Performances of Japanese Womanhood.” American Quarterly 56, no. 4 (2004): 975-1001. https://doi.org/10.1353/aq.2004.0067.

- Musicians from a Different Shore: Asians and Asian Americans in Classical Music. Philadelphia: Temple University Press, 2007.

\begin{abstract}
Although Japanese soprano Tamaki Miura attempted to revive her career shortly after the conclusion of World War II, it was not until her recital on March 21, 1946, in which it became apparent that she was severely ill, that the Japanese media began to pay close attention to her activities. In an attempt to capture the sound of the once worldfamous soprano, Japan Broadcasting Corporation (NHK) arranged three recording sessions with Miura in April, which included an excerpted performance of Puccini's Madama Butterfly. From then to several months immediately following her death on May 26, multiple newspapers including Asahi Shimbun, Jiji Shimpō, Mainichi Shimbun, Tōkyō Shimbun, Yomiuri Shimbun, and others printed articles of various lengths recounting her battles with the illness and, after her passing, commemorating her career. At least three recurring patterns are observable in these and other texts that deal with Miura's final days: the repeated identification of Miura with the fictional character of Cio-Cio-San, the obsessive attention paid to Miura's failing body and voice, and the use of Miura's unflattering demise as a metaphor of Japan in the aftermath of the war.
\end{abstract}

